\title{
The Frontiers of the Roman Empire in Eastern Dacia. Preliminary Results of Research Conducted in the Context of the Romanian National Limes Program
} Alexandru POPA

\begin{abstract}
The visible and invisible traces of the Roman Frontier in Dacia have been, for quite a long time, one of the most representative archaeological sites in Romania, and especially in Transylvania. On one hand, the Roman frontier in Transylvania, also known as Limes, symbolises a border between the GreekRoman world and the local civilisations found in the regions north of the Danube. On the other hand, we rather deal with a large contact zone between the two parts of the antique ecumene. Romania decided to join the international initiative known as Frontiers of the Roman Empire (FRE) UNESCO site by inscribing on the UNESCO Heritage List the components found on its territory - the Dacian Limes and the segments of the Danubian Roman Border. The activity of preparing the nominations is conducted by several institutions. Along with the National Heritage Institute, that is responsible, by tradition, of all the UNESCO nominations in Romania, the activity also involves the National History Museum from Bucharest, the National Museum of Transylvanian History from Cluj-Napoca and the National Museum of the Eastern Carpathians from Sf. Gheorghe. The National Limes Commission has been established to coordinate all the undertaken activities and to assure proper communication between the above-mentioned institutions, both inside the national partnership and with the international partners.
\end{abstract}

Keywords: Roman Dacia, Roman frontier, Limes, National Limes Program.

\section{The Frontiers of the Roman Empire - Towards a modern UNESCO serial site}

The visible and invisible traces of the Borders of Roman Dacia have been, for quite a long time now, one of the most representative archaeological sites in Romania, and especially in Transylvania. On the one hand, the Roman frontier found here, also known as the Limes, symbolises a border between the Greek-Roman world and the local civilisations found in the regions north of the Danube. On the other hand, we rather deal with a large contact area between the two parts of the ancient ecumene. Romania joined the international movement of transforming the Frontiers of the Roman Empire (FRE) into a UNESCO World Heritage site, that represents a huge step in the protection and multiple valorisations of its segments found on Romanian territory. Thus, Romania set out to nominate the Limes of Roman Dacia and 
the segments of the Danubian Borders as parts of the UNESCO ensemble "Frontiers of the Roman Empire".

Within the activity of preparing the nomination dossier for the FRE segments found in Romania, besides the Romanian National Heritage Institute (INP - Institutul Naţional al Patrimoniului) which is, traditionally, responsible for UNESCO nominations, three National Museums are involved in the procedure: the National Museum of Romanian History in Bucharest, the National History Museum of Transylvania in Cluj-Napoca and the National Museum of Eastern Carpathians in Sfântu Gheorghe. Owing to a good coordination of these institutions in working together, and to the coordination of the cooperation with foreign partners as well, the "Limes National Commission" has been set up. Also, in order to "urgently adjust the considerable setbacks that are currently observed between our country and other member countries of the project regarding the UNESCO nomination of this important monument of the antiquity" the Romanian Ministry of Culture started "The National Limes Programme" (ROGOV 2016). The main objective of this multiannual Programme for research and valorisation of research results is setting up "the necessary documentation to classify as historical monuments ... and to nominate on the UNESCO World Heritage List the monuments that once

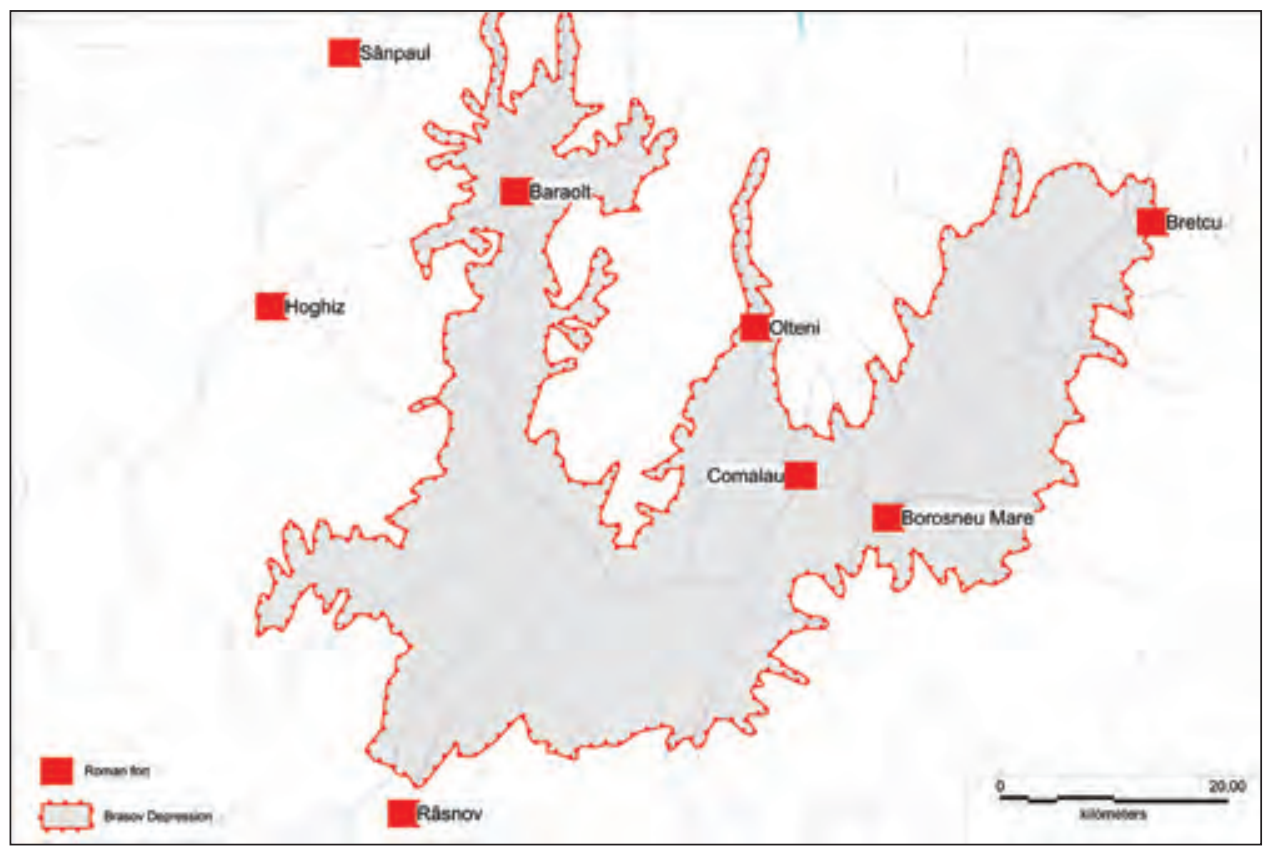

Figure 1. The geographic distribution of the Roman forts in Southeastern Transylvania. 
composed the Frontiers of the Roman Empire" (ROGOV 2016: art. 1) found on Romanian territory.

From an archaeological point of view, the Frontiers of the Roman Empire are characterised by a pronounced spatial and chronologic dynamism. When defining the FRE as an ensemble (serial site) of the UNESCO World Heritage it was more than necessary to impose a series of strict geographic and chronologic limitations. Thus, the Declaration from Koblenz of the Bratislava Group (see UNESCO 2019) defined the Frontiers of the Roman Empire as follows:

"The Frontiers of the Roman Empire World Heritage Site should consist of the line(s) of the frontier of the height of the empire from Trajan to Septimius Severus (about 100-200 AD), and military installations of different periods which are on that line. The installations include fortresses, forts, towers, the Limes road, artificial barriers and immediately associated civil structures" (Popa 2018: 175-176).

In the spirit of this Declaration, the Romanian National Limes Commission drew up the List of sites that compose the Limes of Roman Dacia, which has been forwarded to the Bratislava Group to be inscribed on the UNESCO World Heritage List (Ployer, Polak, and Schmidt 2017: 178-198). The list contains 263 points and has been divided into three segments, according to the responsibilities of each national museum involved in the research project.

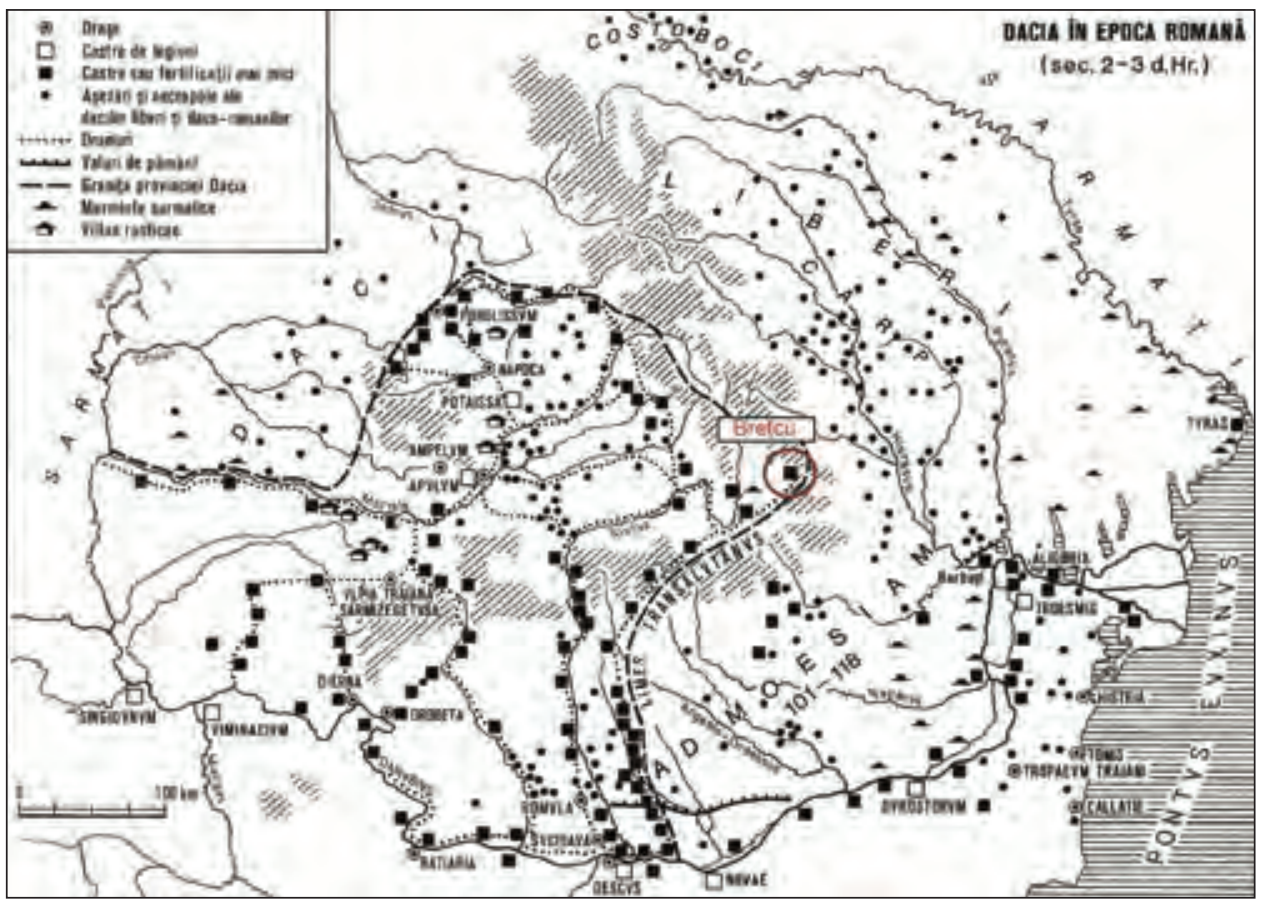

Figure 2. Dacia in Roman times 


\section{The state of research of the sites composing}

\section{the Roman Frontier in Southeastern Transylvania}

Through the decision of the National Limes Commission, the National Museum of the Eastern Carpathians coordinates the activities on the Eastern Frontier of Dacia Province, consisting of sites found on the current territories of Covasna, Harghita and Mureș districts (Ployer, Polak, and Schmidt 2017: 193195). In the following, we will shortly present the results of the documentation activities in several Roman forts, found in south-east Transylvania (Figure 1).

\section{Brețcu}

Within the defence system of the eastern border of province Dacia the fort at Brețcu controlled the crossing over of the Oituz gorge to and from the territories east of the Carpathians. It also assured the contact between Dacia and the cities on the north-western coastline of Pontus Euxinus (Țentea 2013: 69) (Figure 2 ). The fort is situated at the north-eastern end of the modern village, on an inclined plateau (from north to south), at the bottom of Csere Hill, towards the valley of Brețcu brook. The level height between the northern and southern sides of the plateau is of about 6-8 metres. The absolute height of the site varies between 618 and 624 metres NN (Popa 2015b). The local denomination - „Cetatea doamnei Venetur” in Romanian and „Veneturné vár” in Hungarian (Lady Venetur's Fortress) embeds the meaning of a fortification and indicates the existence of traces of "an old stronghold” (Figure 3).

Even today, seen from the outside, the fortification at Brețcu is quite imposing: no matter from which direction one approaches the site, the visitor is greeted by an earth-made rampart several metres high. From inside the fortification, this difference in height is not that noticeable, since compared to the actual stepping level in the fortification the rampart is maximum 1.8 metres higher (Figure 4). The visible remains of the rampart, that cover the fort's walls, spread on a surface of $178 \times 142 \mathrm{~m}$ (Figure 5). Its long sides are oriented in a north-south direction.

One can also notice, at least partially, the remains of the rampart's ditch. These are visible mainly on the fort's eastern side. In the southern part, the defence ditch was eroded in time. Its line is probably marked by the road that passes south of the fort today. North of the fort the defence ditch has been deteriorated by the construction works carried out to build the gas pipe that crosses the region. Towards the west, the defence ditch is used by the locals as an access road to the forest found north of the fort, fact that erodes it actively, year by year. Judging by the situation in the western part of the fort, the fortification at Brețcu had a second defence ditch, visible on a north-south 
direction, on a surface of about 195 metres, found at about 30 metres away from the wall's fortification (Popa 2014: 242, fig. 3-4).

Towers were placed on the fort's rounded corners, built inside the wall. Only the north-western tower has a portion that exceeds the walls with about $1.25 \mathrm{~m}$. The towers on the northern wall are round, having an outer diameter of about $7.40-8 \mathrm{~m}$. The towers on the southern wall are approximately oval, with diameters varying between $4.50 \mathrm{~m}$ and $6 \mathrm{~m}$.

According to the plans published by our predecessors (Gudea 1997: 62-63; Macrea et al. 1951: pl. I) (Figure 5), the outer line of the entrance gates does not outrun the line of the precinct wall. The southern and northern gates were placed each in the middle area of the walls, while the eastern and western gates were placed more towards the southern ends of the side walls. The width of the gates varies between 4 and $5 \mathrm{~m}$. Their bastions are rectangular, with dimensions of about $11.70 \times 7.20-7.70 \mathrm{~m}$.

We need to note the fact that none of the researches conducted in the $20^{\text {th }}$ century nor the more recent geophysical ones has led us to identify intermediary bastions between the corner towers and the gates, such as in the case of other contemporary Roman forts. Another peculiarity of the fort at Brețcu consists in the presence of a second wall inside the precinct. This wall was noticed both through diggings conducted by Panaitescu and Macrea (Macrea et al. 1951: pl. I; Panaitescu 1929: fig. 1), as well as through our geophysical researches (Popa, Cociș, et al. 2010: 127-128).

During the archaeological diggings, researchers documented a $0.80-$ $0.90 \mathrm{~m}$ thick wall. Its foundation is not separated by the elevation through the specific socket. Its stonework is not interwoven with one of the gate bastions or corner towers, being only placed near these. The distance from the inner wall is not a constant one, oscillating on the identified portions between $3.80 \mathrm{~m}$ and $6 \mathrm{~m}$. The results of ground-penetrating radar (GPR) surveys on a segment east of the southern gate confirm the field observations. It indicates the presence of two fallen walls, with earth infill between them. The distance between the two walls is up to about $6.5 \mathrm{~m}$ (Figure 6). The geomagnetic research of several segments of the earth rampart that covers the precinct wall did not generate such clear results as those obtained with GPR. Thus, for the moment, we could not confirm (or infirm) the existence of a second wall on the entire inner perimeter of the fort's precinct. The interpretation of the second wall's function is not clear either, oscillating between that of sustaining the agger to the possibility of representing walls of buildings, placed next to the precinct wall, sometime after the stone fort has been built, probably for optimising the fort's inner space. 


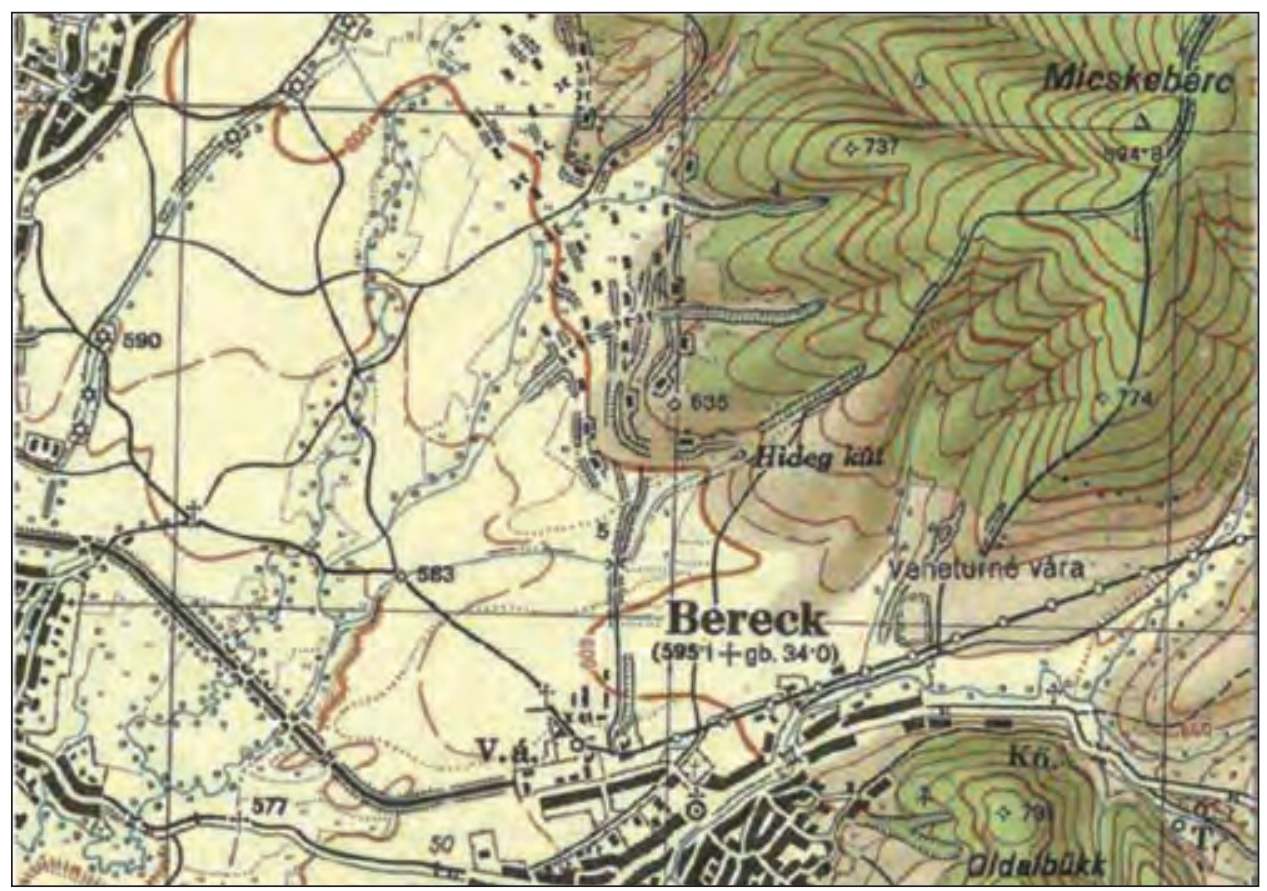

Figure 3. Roman fort at Brețcu on the military map before World War II

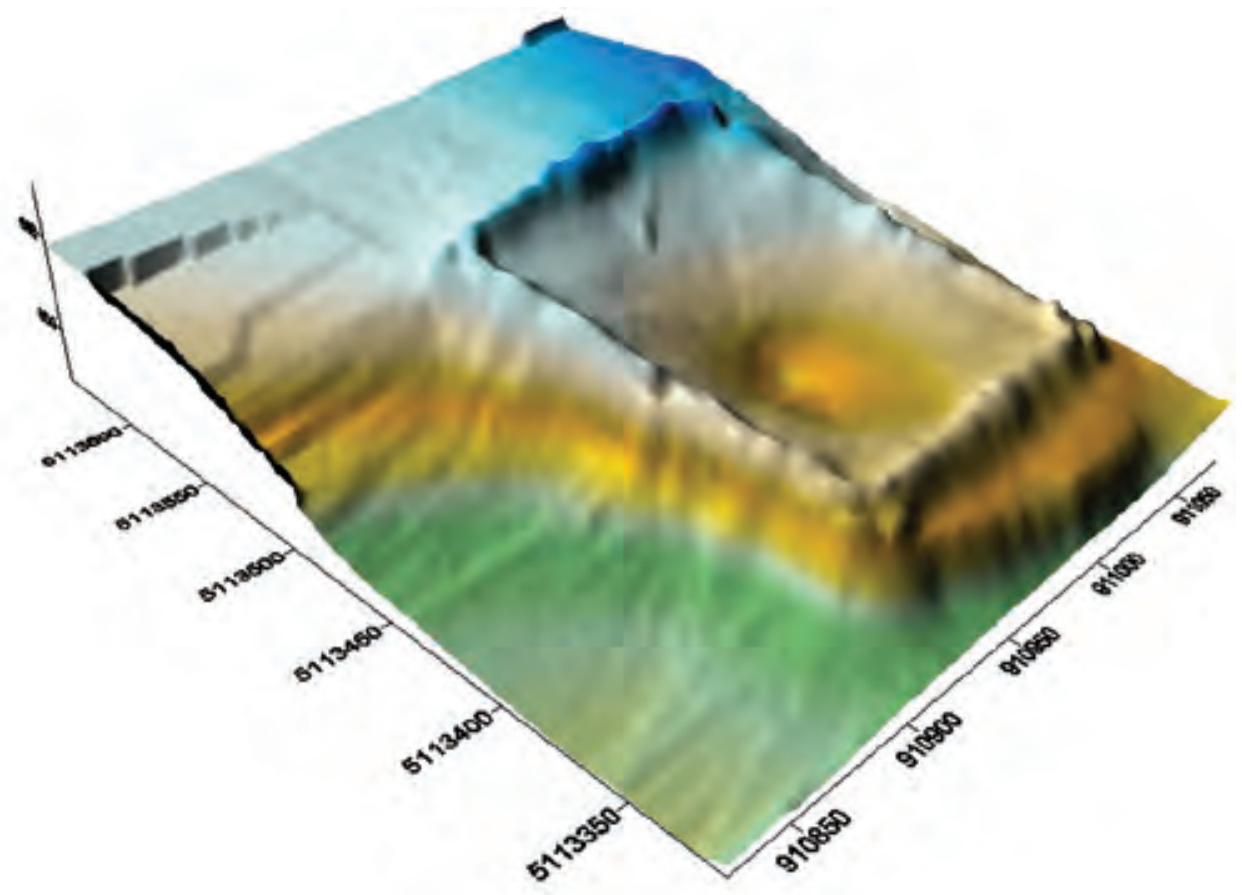

Figure 4. Brețcu. 3D terrain reconstruction in the area of the Roman fort 

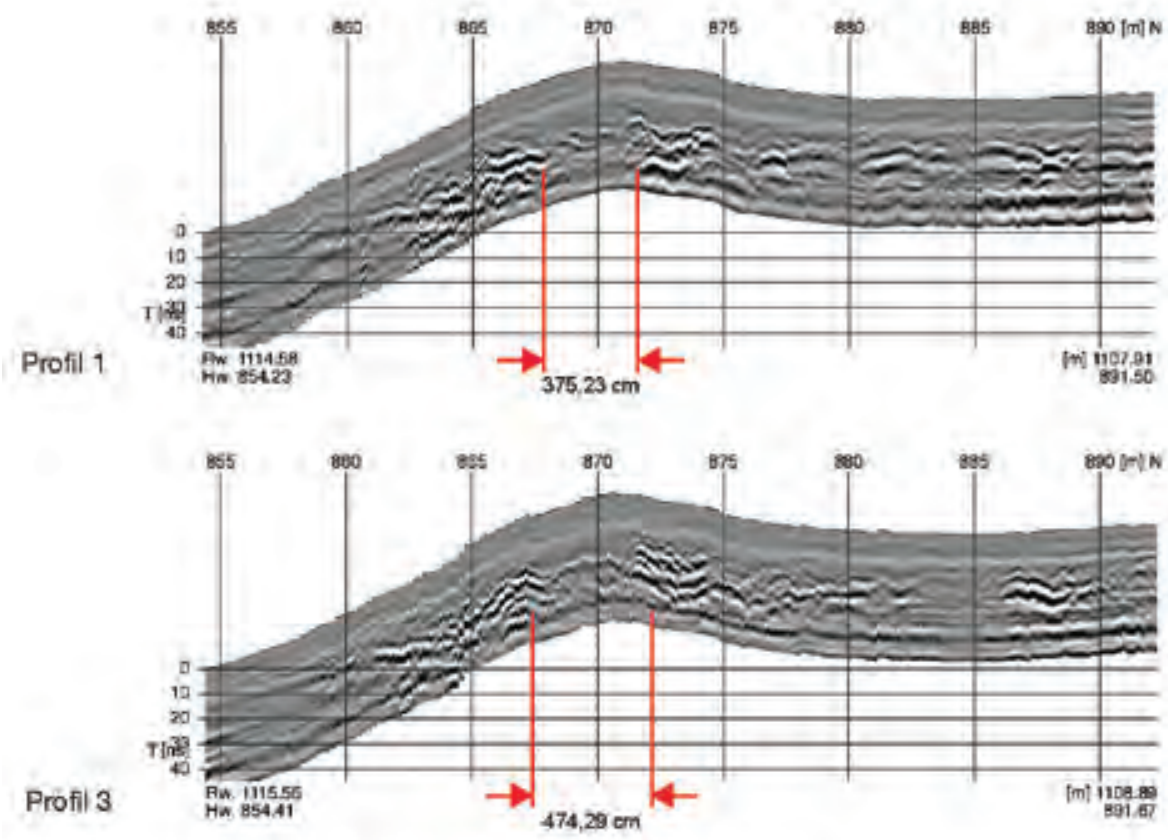

Profil 8

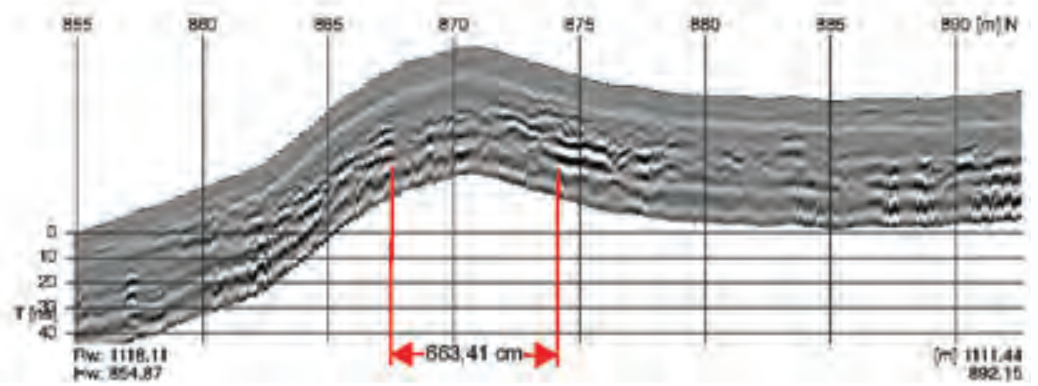

Figure 5. Roman fort at Brețcu. The radargram of the double-wall on the southern side

The fort's inner compartmentation has been mainly researched through magnetometric measurements (Popa 2013; 2014; 2015b; Popa et al., 2010a; 2010b) (Figure 7). We were able to identify a "traditional” inner structure, specific to Roman auxiliary forts, with the three functional areas (retentura, praetentura and latera praetorii), separated by streets placed perpendicularly one to the other (Figure 8).

In latera praetorii we identified the building of the commandment (pincipia), with an almost square shape and sides of about $26 \mathrm{~m}$ in length. It was not possible to establish the details of the compartmentation of the building itself based on geomagnetic anomalies since a series of diggings 


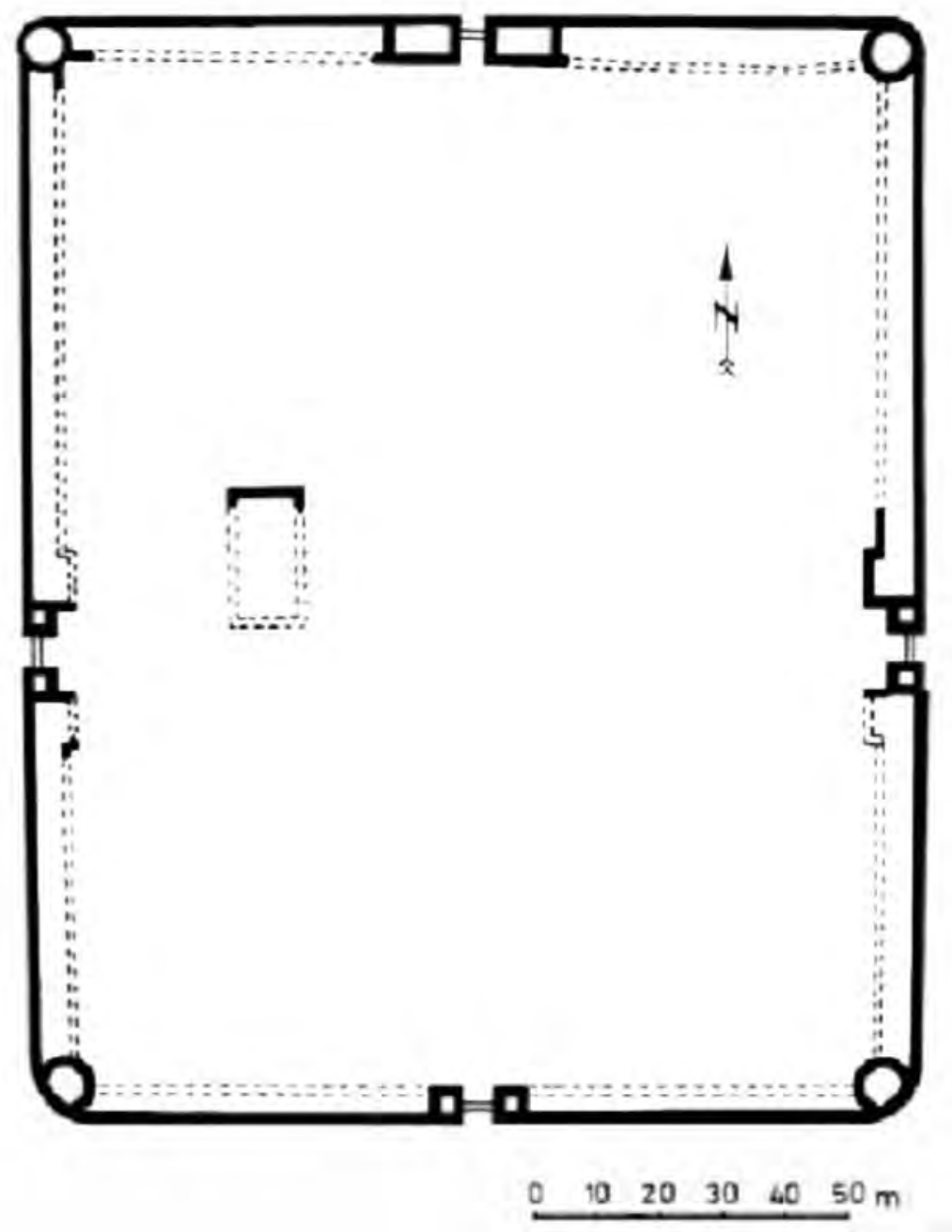

Figure 6. Roman fort at Brețcu. The plan of the fortification

and digging trials were previously conducted. Also, an electricity pole stands today at the surface, right above the ancient building's perimeter, the electric line crossing the fort's entire surface on an east-west direction. On the west of the principia we identified the traces of construction with massive walls, with a total surface of $8 \times 17 \mathrm{~m}$. Its plan fits one of storages usually found in auxiliary forts (horreum). The complex found west of the horreum seems to represent the traces of the commander's dwellings (praetorium), with the dimensions of about $25 \times 25 \mathrm{~m}$. Two other constructions stood oh the East of the principia. Their functionality cannot be identified only through magnetometric researches. 


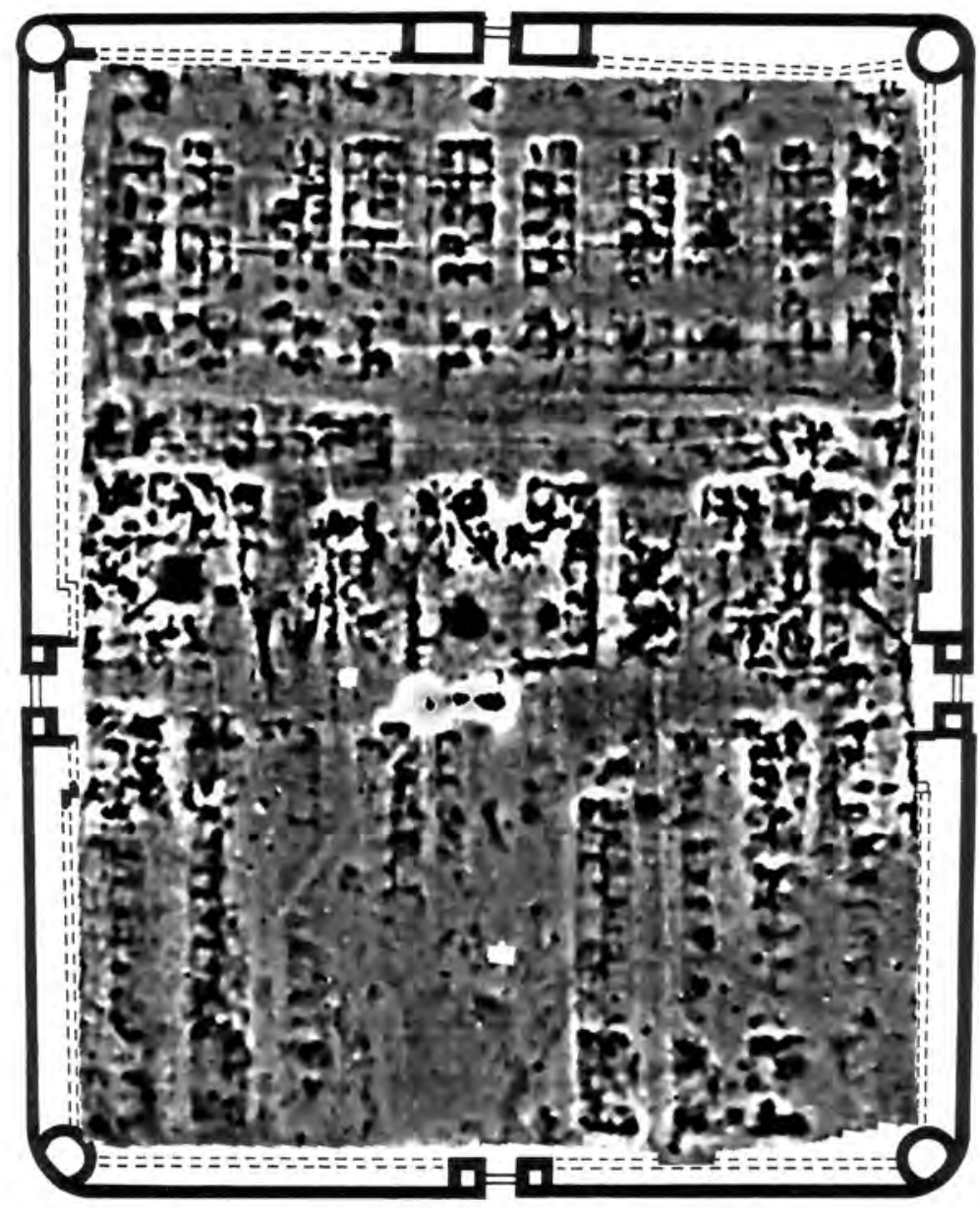

\begin{tabular}{llll}
$0 \quad 10 \quad 20 \quad 30 \quad 40 \quad 50$ \\
\hline
\end{tabular}

Figure 7. Roman fort at Brețcu. The results of the magnetometric researches in the intramuros area

In the retentura we managed to identify at least ten barracks disposed per striga (perpendicularly on via principalis). Besides these, on via quintana one can observe anomalies generated by two other elongated constructions. Judging by their dimensions they could be barracks disposed per scamna. The anomalies of the barracks disposed per striga reach the length of about $33-34 \mathrm{~m}$. Their width could be of about $7 \mathrm{~m}$, to which we have to add a porticus of about $1.8 \mathrm{~m}$. The compartmentation of the space in the retentura shows symmetry compared to via decumana: towards the corners there are two barracks placed next to one another, and towards the middle, in front of 


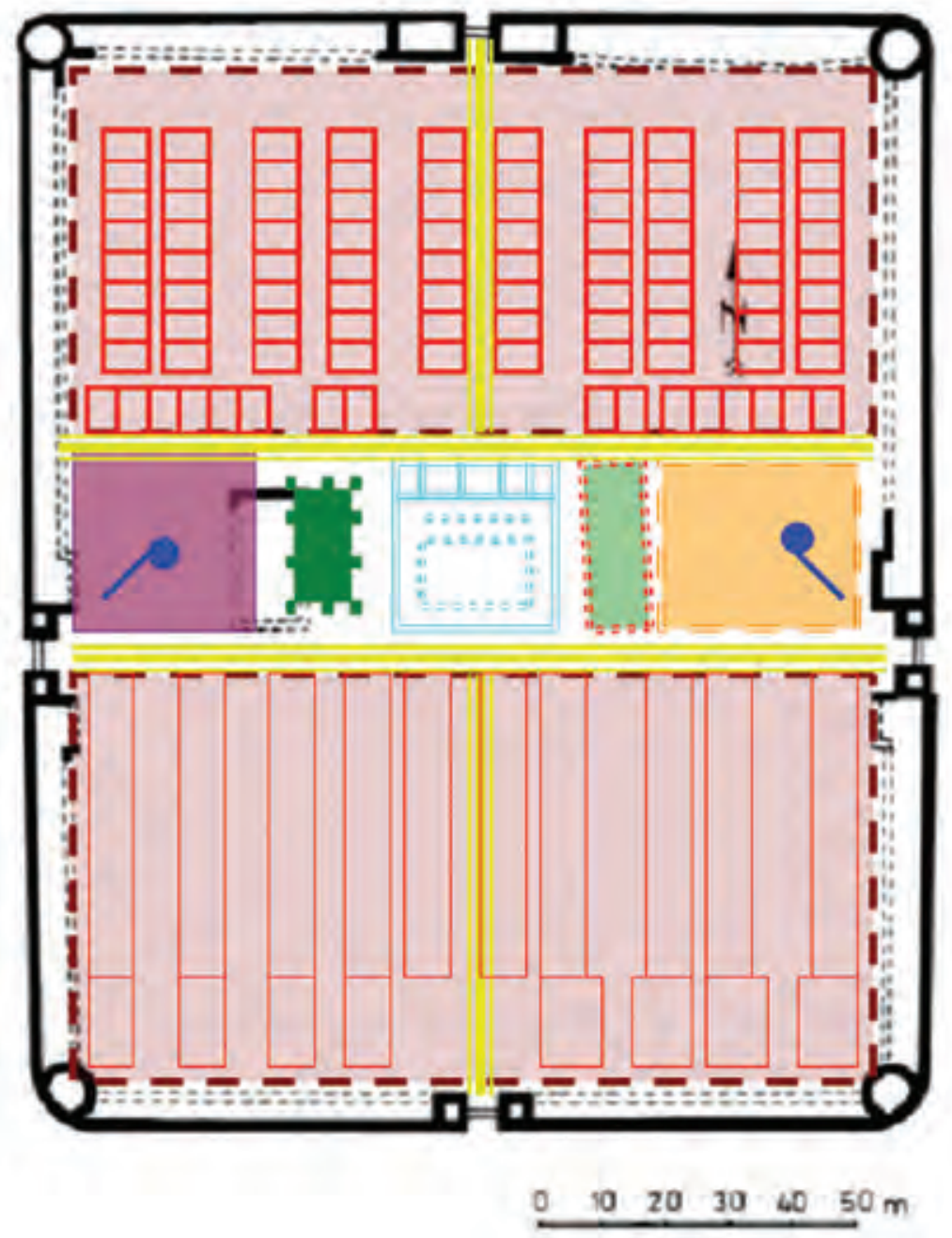

Figure 8. Roman fort at Brețcu. Hypothetical reconstruction

porta decumana-a simple barrack, placed facing backwards via decumana and the portico-on the other side. The geomagnetic anomalies from the retentura allow us to estimate that the barrack in this area were compartmented in 8 contubernia each. Since we could not distinguish in their structure the socalled "Kopf bauten" in their structure, that should represent the dwellings of the centurions, we consider that the barracks disposed of per scamna could have been used for the latter ones, their dimensions being of about $7 \times 40 \mathrm{~m}$. We also admit the possibility that these two constructions, disposed along the via Quintana, could have been part of the latera praetorii and thus could have been used for a different purpose than the one mentioned above. 


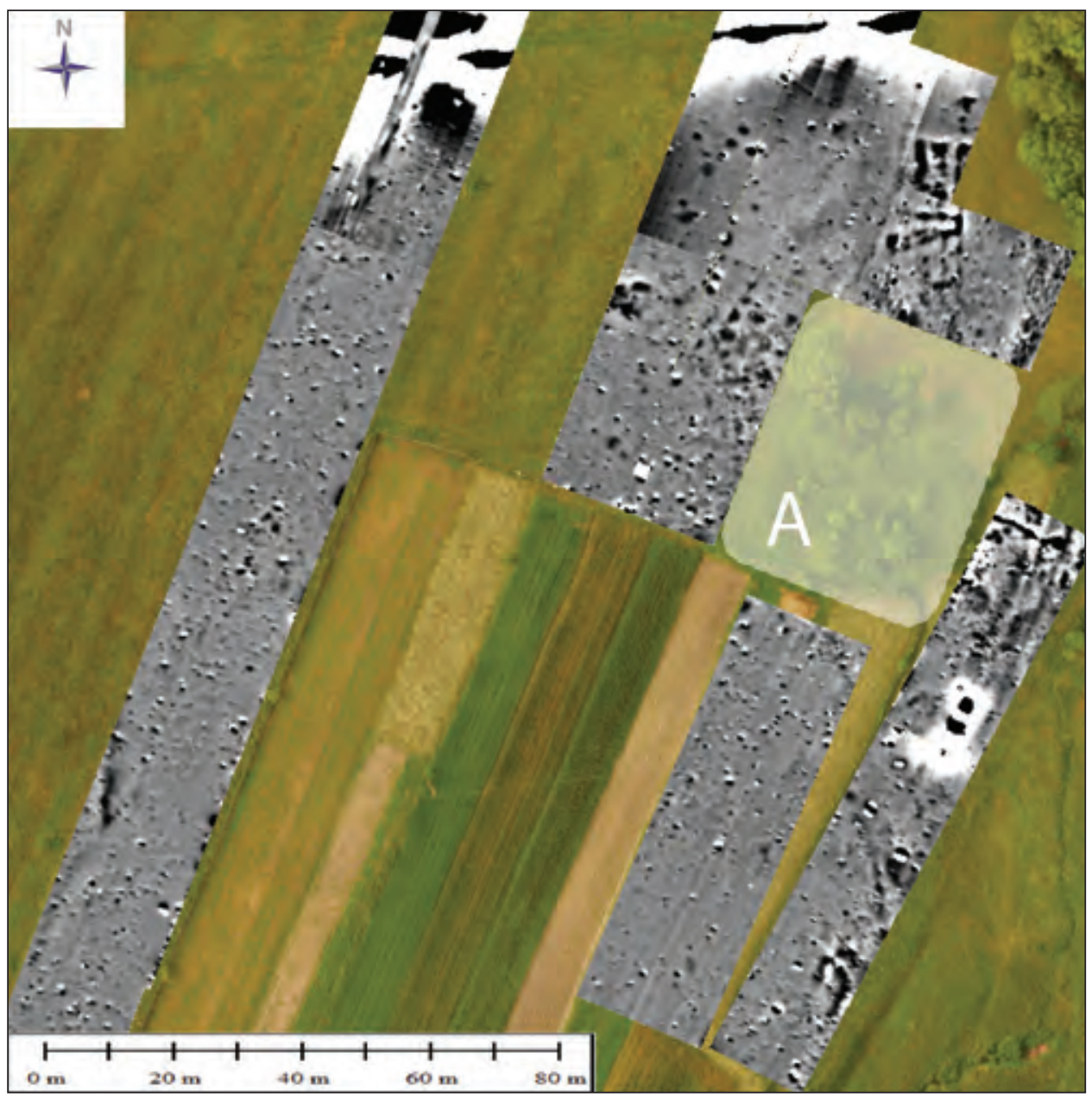

Figure 9. Brețcu. The results of the magnetometric research in the area of the baths. A - the ruins of previous archaeological excavations

In the praetentura one can notice barracks disposed of per striga, which could have been $58-60 \times 8-10 \mathrm{~m}$. We were able to distinguish with certainty the geomagnetic anomalies of at least eight barracks - four on each side of via praetoria. Based on much weaker geomagnetic anomalies (as, for example, those disposed of in front of the corner of the commander's building, next to the praetentura dextra) we can assume the existence of two more barracks of the same shape and size. Thus, we have ten barracks also in the praetentura, although these have a different structure than the ones in retentura. One can also notice that the geomagnetic anomalies are more pronounced on the northern side of the barracks. This fact shows that there have probably been some floor arrangements or even heating systems in the rooms. On its width, this side of 
the barracks in praetentura also includes the porticus. Since we are dealing with military troops that include cavalry, we estimate that this "Kopfbauten" was meant for the herd's decurion. Judging by the situation in praetentura dextra, where the geomagnetic anomalies are more pronounced, we can estimate that each of the ten barracks consisted of a dwelling for the decurion and 12 contubernia (Popa 2015b: 83, fig. 4).

In the context of preparing the scientific documentation for the UNESCO nomination of the site, we needed to establish its external limits. Thus, we conducted geomagnetic prosecutions on large areas outside the fortification. The scientific challenge for this research consists of the existence (or inexistence) of traces of a human settlement outside the fort, in its immediate vicinity. As a result, the more than 8.5 ha that we prospected geomagnetically east of "Veneturné vár" plateau did not reveal many traces of inhabitancy, specific for the surroundings of most of the Roman forts known until now. We can assume that no civilian settlement has developed in the area, at least on the way from the fort towards the Oituz Gorge.

We identified the baths on the west of the baths. These are found at about 85$90 \mathrm{~m}$ from the western gate, on the spot known by the locals as "Pince"/"Pivniță" ("Cellars"). The archaeological diggings conducted by Panaitescu researched a complex consisting of at least 9 rectangular rooms (Panaitescu 1929: fig. 1). The complex was found on the banks of a brook with no name that flows into the Brețcu River (Popa 2014: 242, fig. 3). The magnetometric researches showed the presence under the surface of magnetic anomalies that seem to outrun the limits of the diggings conducted in 1925. For the following period, we have planned a series of magnetometric measurements in this part of the extra muros area, to identify precisely the civilian settlement found near the fort at Brețcu (Figure 9).

Summarizing the above-presented information, we can conclude that the recent researches in the fort at Brețcu allowed us to identify the precise traces of inhabitancy in the extra muros area, east of the fort. On the west of the fort we have found the presence of massive anomalies belonging to the fort's baths. Besides bringing a better understanding of the general situation of the site, our researches will also contribute to establishing and extending the site's protection area.

\section{Boroșneu Mare}

Today, Boroșneu Mare is today the administrative centre of the commune with the same name. It is found $17 \mathrm{~km}$ away from Sf. Gheorghe. The site is located on the high terraces of Covasna brook, at the edge of a piedmont with a smooth slope, that reaches the limit between the hydrographic basins of the Olt and 


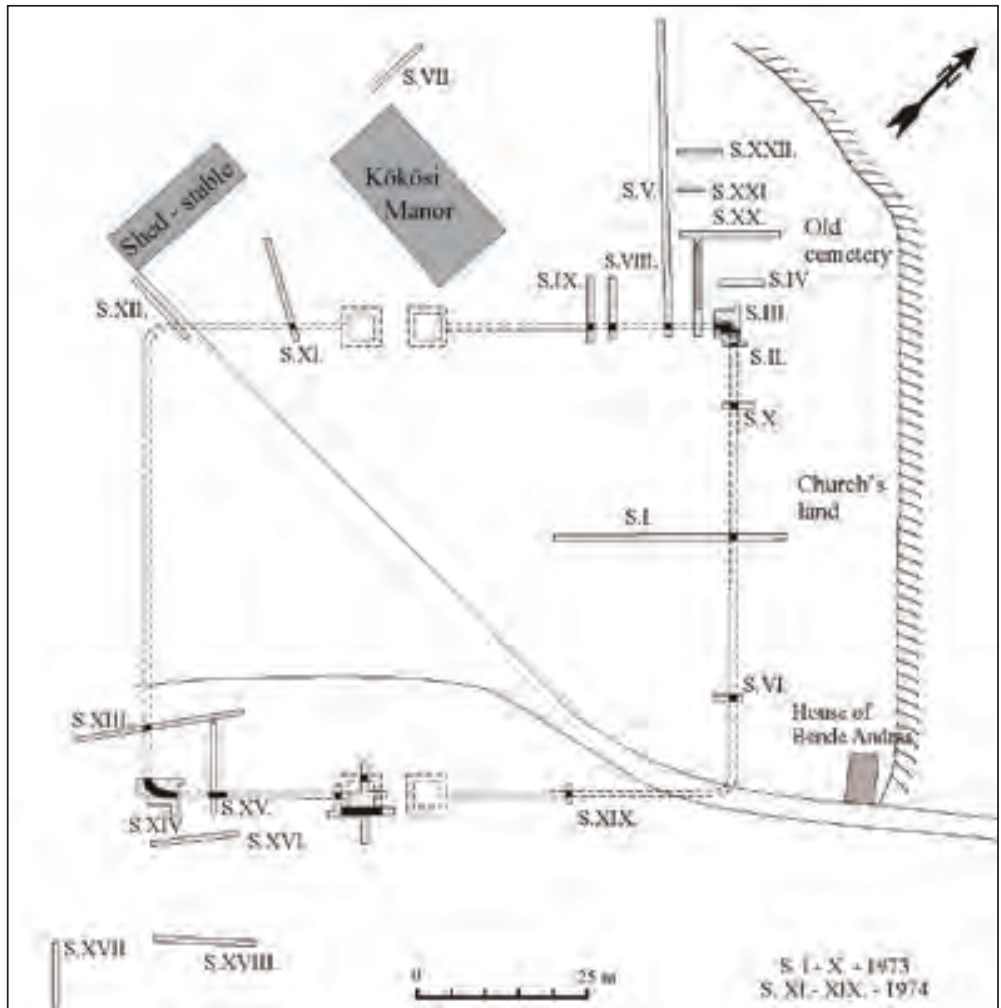

Figure 10. Boroșneu Mare. The plan of the excavations conducted in 1973-1974 with a reconstruction proposal of the fortification walls as seen by Z. Székely

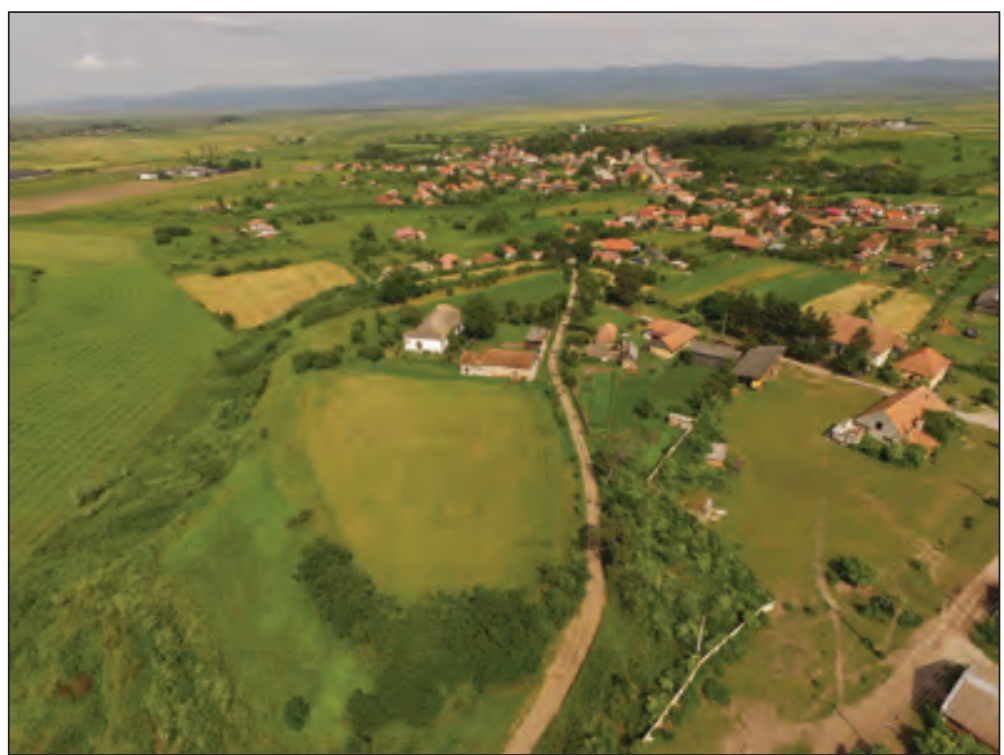

Figure 11. Boroșneu Mare. Aerial view on the area where the presumed Roman fort lies 
the Buzău rivers near Valea Mare (Țentea 2013: 69-70). The first written information regarding the existence of some ruins on the village's perimeter dates to the period known as "the archaeology of priests", when, in 1864, the traces of some old buildings were mentioned in the village's southern side. The first archaeological entry about the site dates in 1888, when Gábor Téglás mentioned the discovery of Roman artefacts in Boroșneu Mare. Archaeological diggings were conducted in 1911, 1947 and between 1973 and 1974. According to modern-day archaeological research standards, the field documentation of these diggings was quite sketchy, being characterised by a very imprecise topographic documentation. Thus, we consider the interpretation of their results to be somewhat tendentious, formulated in the a way to serve the dogma of the political propaganda of those times (Székely 1975).

The archaeological materials kept by the National Szekler Museum from Sf. Gheorghe reflects only partially the results of the diggings. The ceramic material brought to the museum and said to come from these diggings could not be attributed to any complexes or stratigraphic levels. We could not find, for the moment, the possibility of putting together a horizontal stratigraphy of the archaeological material originating from these diggings (Bordi and Popa 2013).

Nevertheless, based on previous researches, we can assert that during the existence of Roman province Dacia there was a Roman military fort at Boroșneu Mare, having the dimensions of approximately $130 \times 198 \mathrm{~m}$ (Figure 10). Based on the tegular and epigraphic materials we can deduce the name of at least five auxiliary troops of the Roman army, which were stationed at some point in time at Boroșneu Mare. The archaeological chronology of the fort is deducted from the historic chronology of Dacia province. From an archaeological point of view, neither the moment nor the circumstances in which the fort was have been known to us so far. We don't know its evolution phases, and we do not have information about when the community ended its inhabitancy here. In the following period, we plan a series of archaeological and multidisciplinary investigations that we hope will shed some light on solving these and many other issues related to the research of the Roman site at Boroșneu Mare. Found at only $35 \mathrm{~km}$ in a straight line from the camp at Brețcu, the fort at Boroșneu Mare finds itself in a very different situation today. First, there are no visible traces at the surface. Second, as opposite to Brețcu, the site at Boroșneu Mare is totally covered by the modern village. Thus, the field is highly parcelled, belonging to many owners, being covered by houses and other utilitarian buildings (Figure 11). All these circumstances make it even harder for us to document the fort at Boroșneu Mare. Nevertheless, it was decided to nominate the site on the UNESCO tentative list. 


\section{Comolău-Reci}

The archaeological site is known as "the Roman camp at Comolău" is found at approximately $10 \mathrm{~km}$ east-south-east of Sf. Gheorghe city, the Municipality of Covasna District (Figure 12). The site is found within the present territory of Reci commune, at about $2 \mathrm{~km}$ west of its centre, on the border of Comolău quarters. Up until the seventh decade of the $20^{\text {th }}$ century, this area used to be a settlement of its own, a separate village. The fortification is bordered by defence ditches on its northern and western sides. Its eastern side is bordered by the deep valley of the Comolău brook and the southern one by the high terrace of the Negru ("Black") River. As time passed, an exquisite shape of relief was created here. It looks like a truncated cone-shaped pyramid, with asymmetric pentagonal bases, rising above the plateau's level (Figure 13). The fortification has relatively abrupt banks, of about $35-40^{\circ}$ (Figure 14). They are interrupted only by slight terracing, with a width of about $2-2.5 \mathrm{~m}$. This terrace may be observed mainly in the aerial photographs, surrounding the fortification's plateau, at about 3-4 metres from its upper limit. The site covers a surface of about $7.500 \mathrm{~m}^{2}$ (Popa and Bordi 2016).

The fortification's interior is plain, without any traces of walls. The only dishevelment visible today on the plateau's surface is the tamped traces of the archaeological excavations. One may observe these mainly around the towers since they were left uncoated at the end of the researches in 1942. The defence ditches are the only visible elements of the fortification at Comolău, that still impress today the by-passers due to their very large dimensions. On its northern

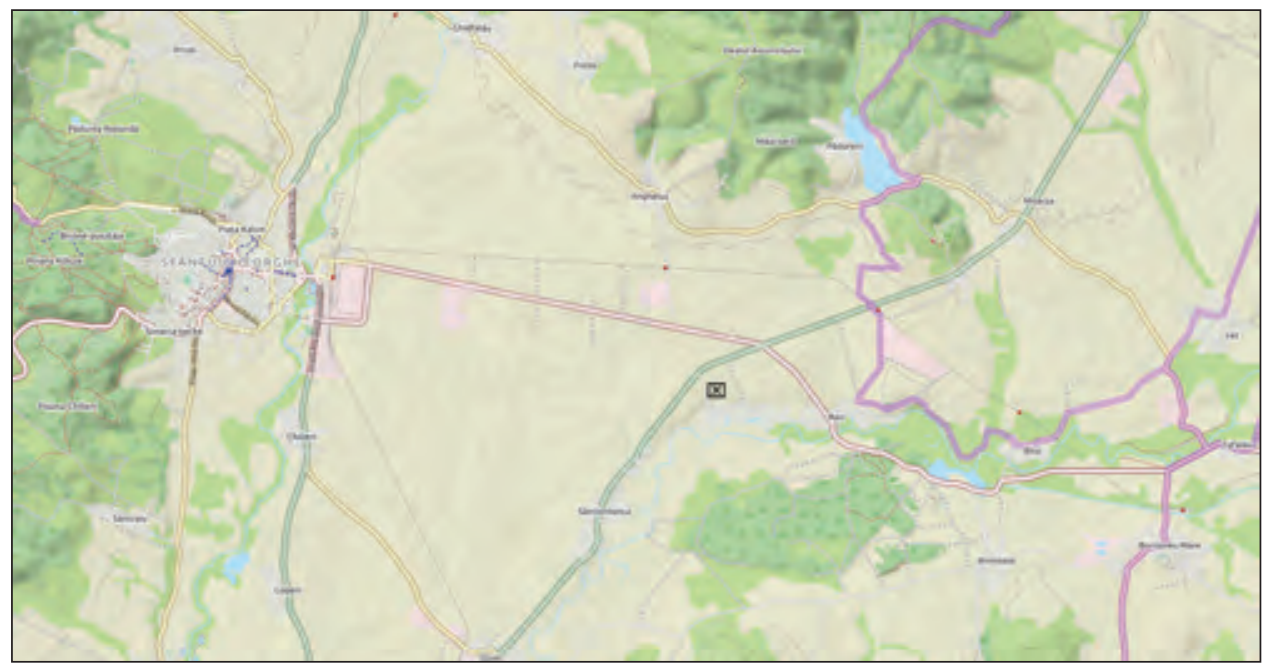

Figure 12. Comolău - Reci. The site's geographic position 


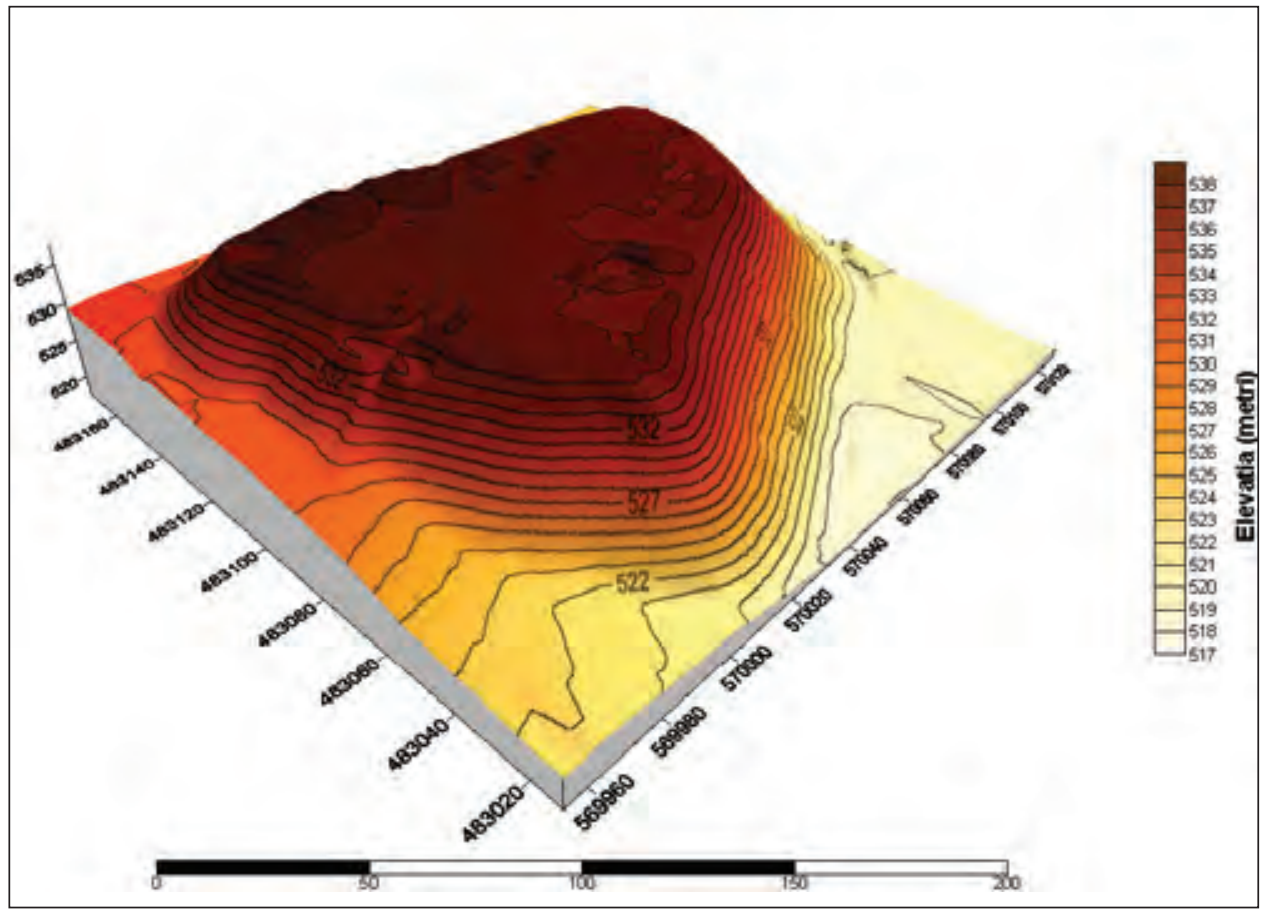

Figure 13. Comolău - Reci. A 3D reconstruction of the land

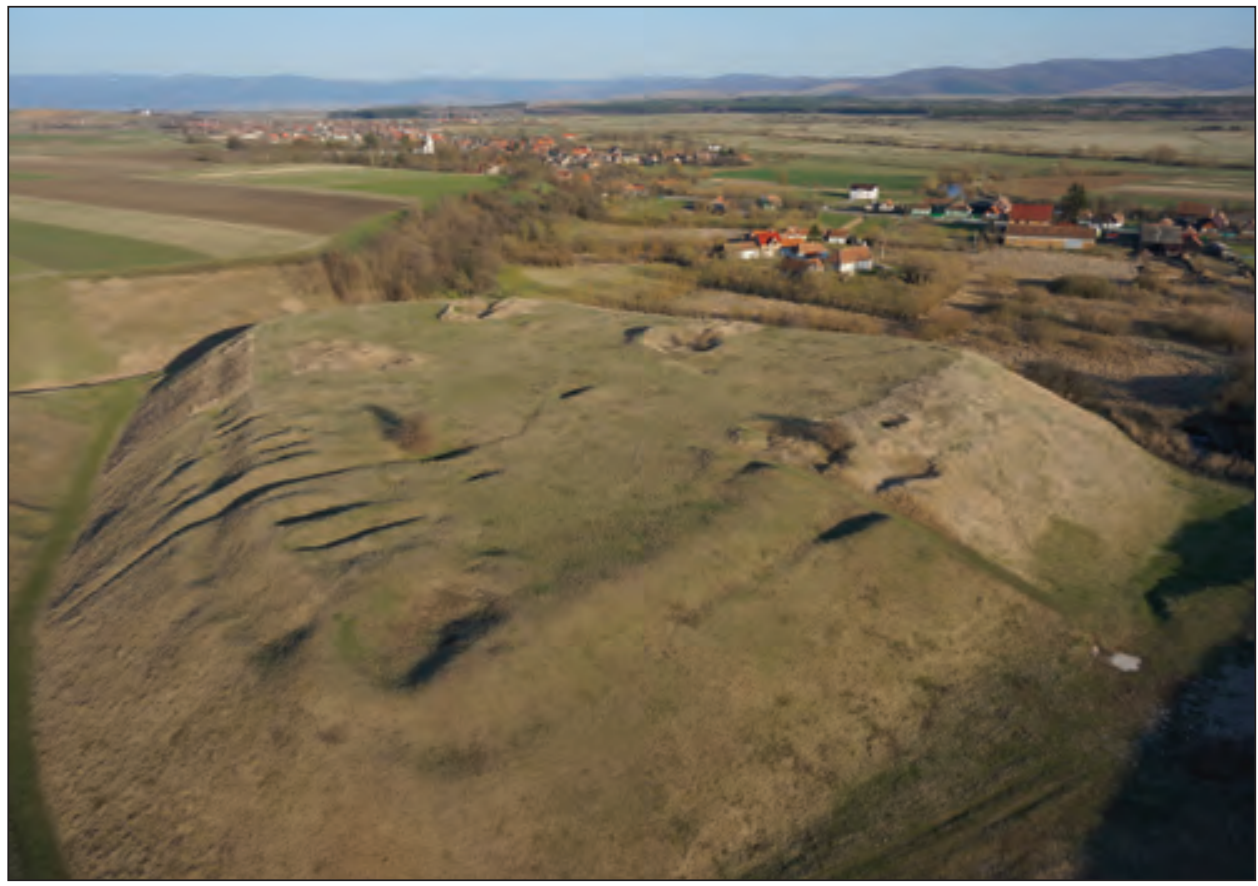

Figure 14. Comolău - Reci. Aerial view of the fortification 


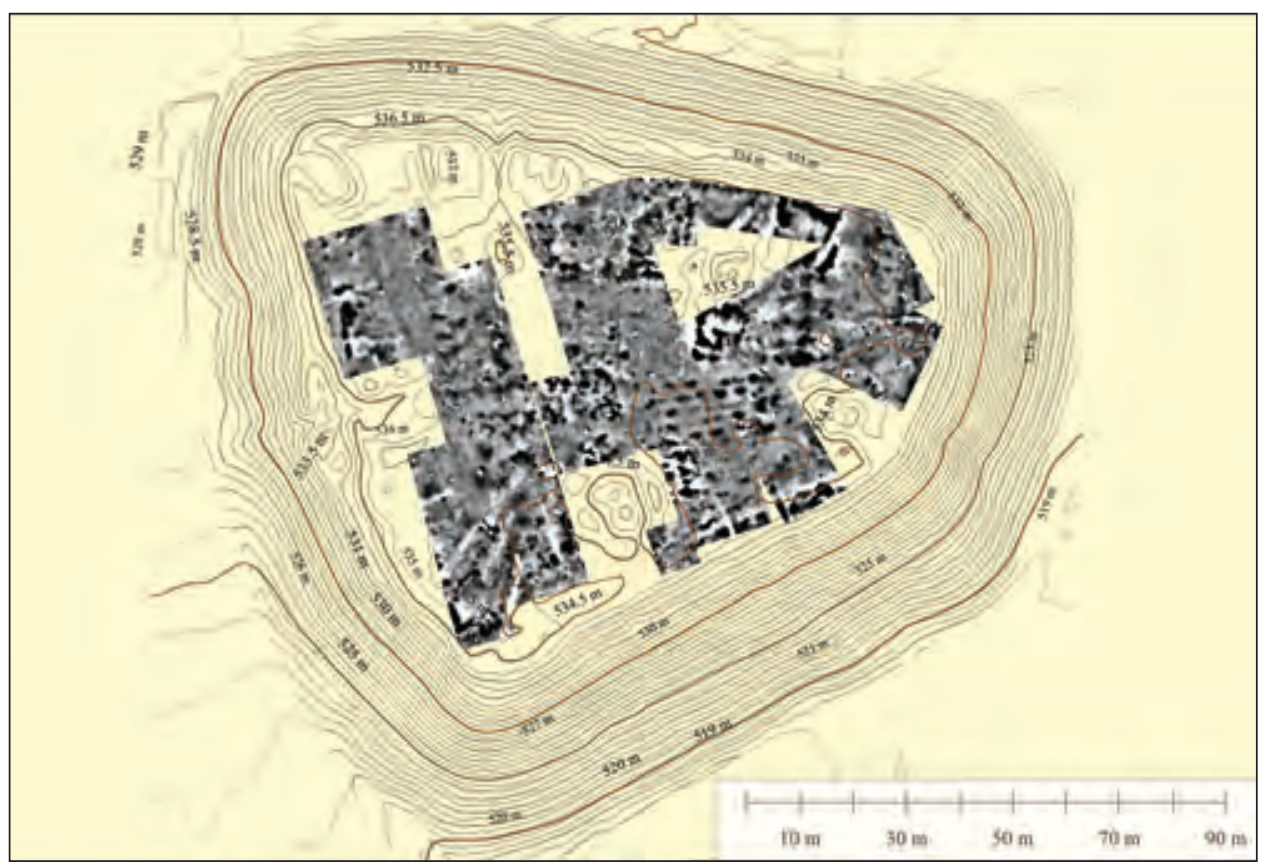

Figure 15. Comolău - Reci. The results of magnetometric researches in the fortification

side, the ditch is "V"-shaped. It is 200 metres long and 40 metres wide towards its western end and 47 metres wide on the eastern one. Towards its western end, the ditch is 6-7 metres deep, while on its eastern limit it deepens, even more, adding 5 to 6 metres to the initial depth. As one may observe in the aerial photographs the ditch was cut following the edge of the former Comolău brook, running in parallel with its line. There is only a narrow crest kept until today between these elements. It seems to have assured double protection from the north-west. Thus, the northern edge of the valley is found at about 100 metres far from the fortified plateau. The western ditch is about 160 metres long, being 65 metres wide today. This segment of the fortification is channel-shaped, with a depth of about 6-7 metres at its northern end and of about 15 metres at its southern one. We cannot establish today whether these were the original shape and dimensions of the ditch or they are a direct result of soil erosion and construction works of the nearby road that ties the former Comolău village to the National Road no. 11 (E574). The fortification's eastern side is defended by the Comolău valley, on a length of about 70 metres. Here the ditch is also "V"-shaped, being 16 metres deep and 68 metres wide. On its southern side, the fortification is bordered directly by the marshy valley of the Negru River, and it seems thus it hasn't been fortified (Popa and Bordi 2016). 
Many field types of research and observations were conducted at Comolău as early as the $18^{\text {th }}$ century, started by József Benkő and continued by several scholars of that time, among which we can distinguish Balázs Orbán. There were three archaeological excavation campaigns conducted at the site, in 1909/1910, 1942 and 1949, but their results were only partially published. Due to this situation, we have given quite a large space in our work to reconstruct and reinterpret the results of former researches and excavations, starting from the little information comprised in the available and rather pauper field documentation of the time and with the few archaeological materials still found in museum collections. Besides these aspects, the volume also valorises the results of our own researches, of the magnetometric surveys conducted at the site during 2012-2018 (Figure 15).

Our result is linked directly to the origins of the fortification. The most important argument brought so far by our predecessors that could prove its Roman provincial origin is the rich archaeological material of Roman origin discovered at the site. Unfortunately, this material loses its value as a defining element, since, at the time of discovery, a clear stratigraphy that could link, without any doubt, these materials with the actual walls of the fortification, has not been done there. The second argument was the presence of Roman military equipment and weaponry among the discoveries. This argument can also be ignored, since most of these pieces may have been easily used both in the Roman and in the post-Roman period.

The large dimension of the defence ditches also pleads also against the fortification's Roman character of the fortification. For comparison, we do need to mention that the Roman military fortifications in south-east Transylvania had quite narrow defence ditches, as for example those at Boroșneu Mare that were 4.5 metres wide, those at Brețcu that were 4-4.5 metres wide, those at Olteni that were about 7 metres wide or the double ditches at Râşnov, that were each 3 metres wide each. These large defence ditches are more specific for the Medieval Period, being found at Feldioara, where the ditch is about 35-40 metres wide, at Leț-Cetatea Várhegy, where it is 20-25 metres wide or at "Cetatea Ciuntită" from Odorheiu Secuiesc, where the ditches are 20 metres wide (Popa and Bordi 2016).

The actual excavation of the ditches and the fact that the soils that were dug out were carried up to the top of the fortification's plateau, which is higher now than the surrounding plateau, could explain the presence of this rich, but rather fragmentary, archaeological material. The same situation is found at Leț, where archaeologists found a large amount of prehistoric materials but 
no archaeological complex that could explain the presence of these materials. To the same extent we may also mention the thickness of the precinct wall. Thus, the Roman camps found in the area have much thinner precinct walls. These are of about 1.35 metres at Boroșneu Mare, 1.10-1.20 metres at Brețcu, or 1.00-1.20 metres at Olteni. At Comolău the precinct wall was about 1.80 metres thick near the north-western tower. Judging by this dimension, the fortification at Comolău is rather like the Leț medieval castle, that has a 1.6 metres thick precinct wall or to the fortified church at Sf. Gheorghe, which has a 1.7-1.8 metres thick precinct wall. Both last mentioned fortifications were built in the $16^{\text {th }}$ century. Still, we cannot certainly state that the fortification at Comolău belongs to this period.

Summarizing the results of our researches at and about the Comolău fortification, we may observe that the Comolău plateau has been inhabited since the Bronze Age. Judging by the discoveries of military origin the Roman settlement, may have been either military or civilian one, and its life began, at latest in the fifth decade of the $2^{\text {nd }}$ century the last, lasting for about elven decades. We cannot exclude the hypothesis that a previous civilian settlement may have been transformed, into a military station during the $3^{\text {rd }}$ century. After the Roman retreat and the abandonment of Dacia, the Comolău plateau was inhabited by the bearers of the Sântana de Mureș-Černjachov culture, who lived here at least until the eight decades of the $4^{\text {th }}$ century. After a period of about eight centuries, the plateau was inhabited once again during the $13^{\text {th }}$ century, when the Szeklers settled in south-east Transylvania. The plateau might have been fortified also during the $16^{\text {th }}$ century when the Civil War took place in Hungary (1526-1539) and this region was invaded several times. Unfortunately, these conclusions are only hypothetical. In order to reach more firm and sustainable affirmations, we need to retake the field researches through archaeological excavations. We need to survey the structures that were discovered during the $20^{\text {th }}$ century. Until we can do that, the fortification at Comolău remains a site that raises a lot of questions without giving any answers.

\section{Olteni}

The camp at Olteni is found in the eponymous village in Bodoc commune, Covasna District. The fortification rests on a high terrace on the right bank of the Olt River, superposed by the castle built in 1827 and known today as "Castelul Mikó"/the "Mikó Castle" (Figure 16). The fortification finds itself right in front of the area where the Olt River's valley narrows significantly, before crossing through the gorge from Sf. Gheorghe Depression towards Ciuc Depression. The historical traces dated in the Roman period were 


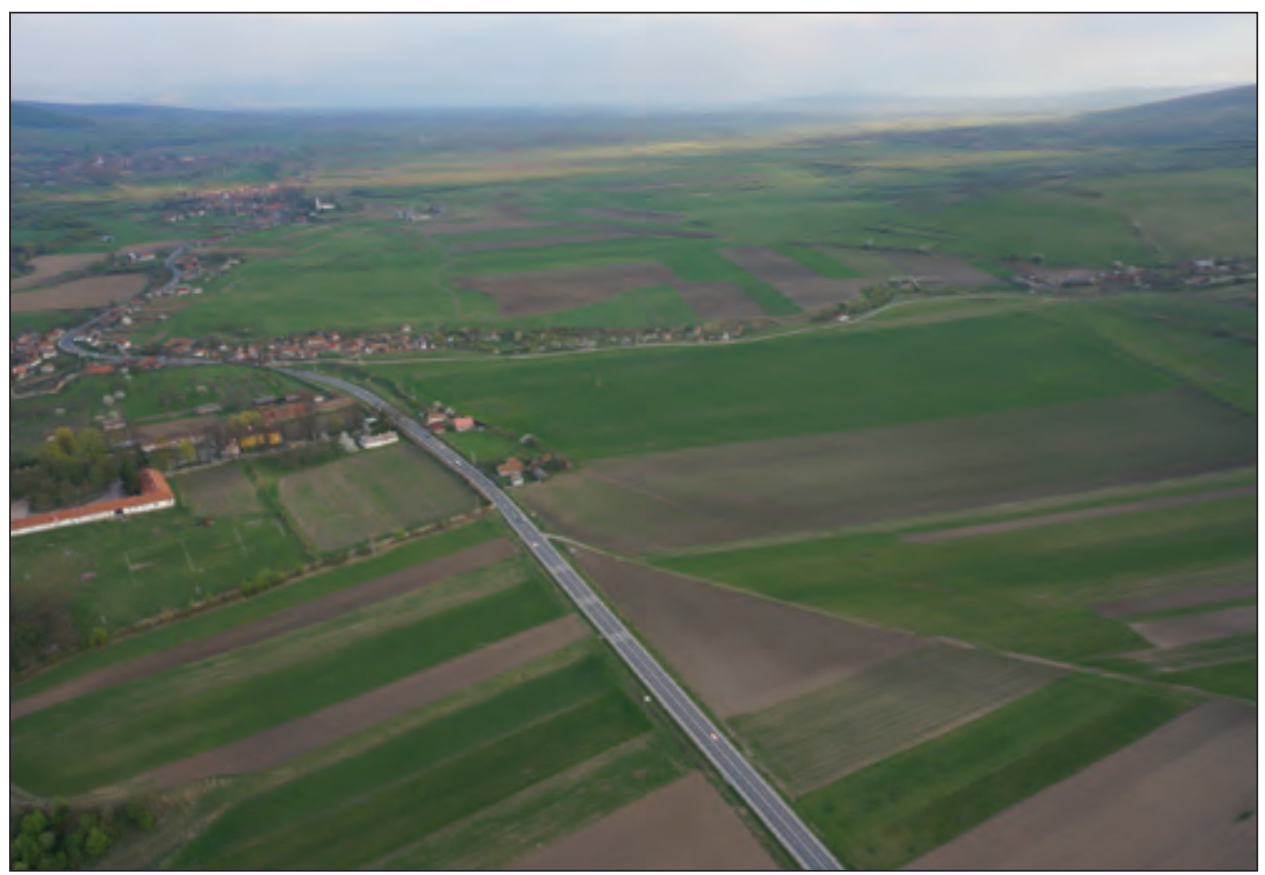

Figure 16. Olteni. Aerial view (from the north) towards the Roman fort

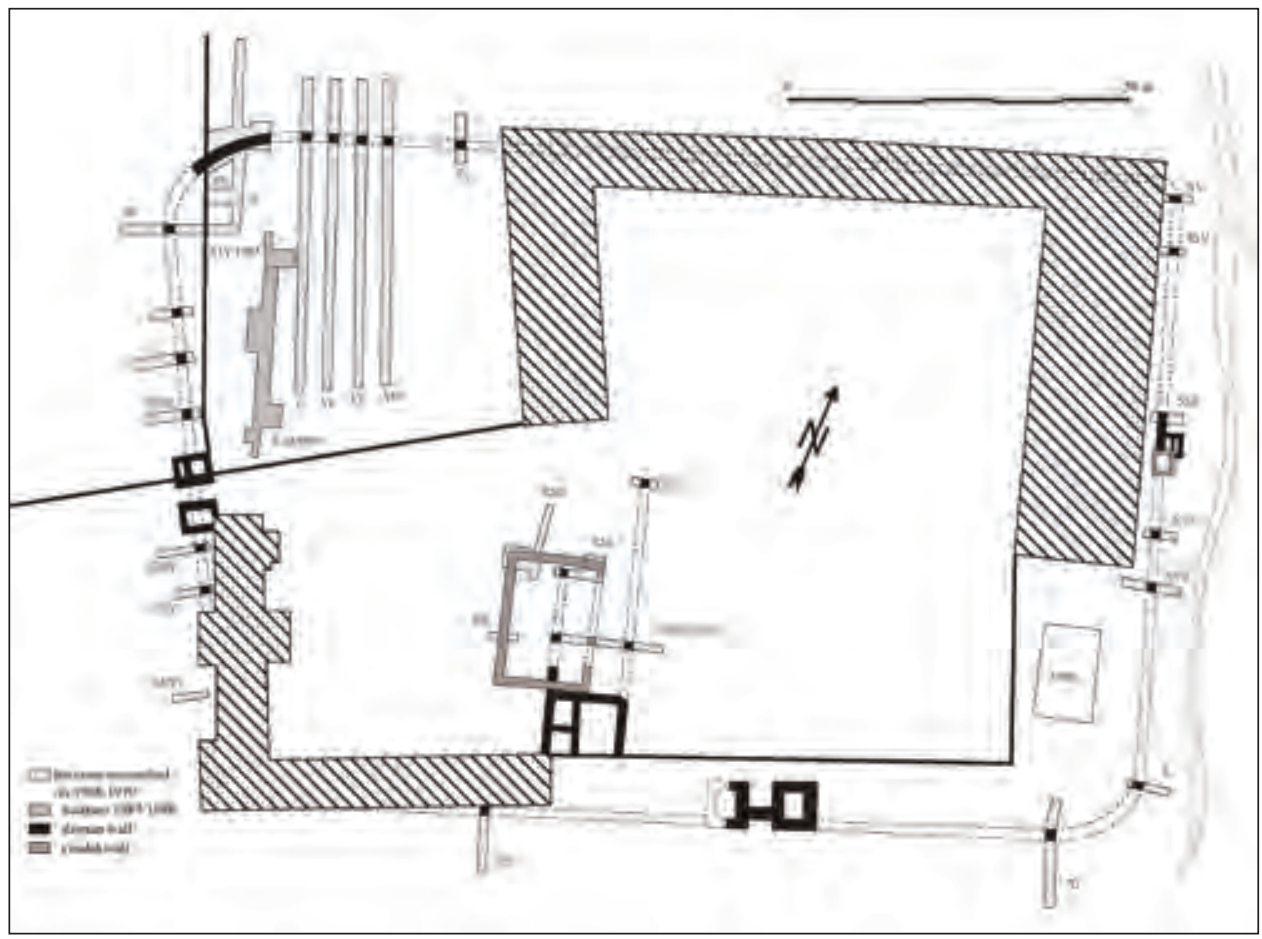

Figure 17. Olteni. The general plan of the excavations conducted by Z. Székely 
presumed back in 1795, and quite systematic archaeological researches were conducted in 1947, 1949, 1968-1970 and in 1987-1988 (Székely 1993) (Figure 17). Between 2012 and 2017 we have conducted small scale magnetometric surveys in some of the camp's inner areas. In 2018, within the National Limes Programme, we have conducted extended magnetometric surveys in the extra muros area, covering a surface of about 9.5 ha. The surveys covered a representative segment of the Olt river valley. The main objective of these researches consisted of identifying the traces of the civilian settlement found close to the military fortification at Olteni. This objective was reached by discovering a series of specific magnetic anomalies. The geomagnetic researches helped us identify the areas that will need a more thorough approach while preparing the scientific documentation for the UNESCO nomination dossier „The Limes of Roman Dacia”. We deal with a series of rectangular structures that indicate explicitly and precisely the location of archaeological complexes of the civilian settlement, or maybe of its necropolis. The results of these investigations allow us not only to better understand better the position of the Roman military fortification at Olteni within the field, but also to assess the limits of the site and its protection area, which are extremely important within the UNESCO nomination process.

\section{Baraolt}

The "Véczer" or "Véczer farka" point close to Baraolt town is known as a Roman site. The place is found approximately $3 \mathrm{~km}$ south-west of the town centre, northeast of the intersection of two roads - the one from Augustin to Baraolt and the one from Racoșul de Sus to Căpeni (Figure 18). The presumed Roman camp found next to the second-largest elbow of the Olt River, where the water flow changes its course, redirecting from south-north towards east-west, had been mentioned for the first time in the $19^{\text {th }}$ century publications (Cavruc, Bartok and Bărbulescu 1998: 38 7b). The site is also mentioned by B. Orban and C. Gooss, but we appreciate the information they provide to be too unclear and superficial. We find a more or less reasonable discussion in a work signed by Paulovics in 1944. Later (in 1949) a team led by C. Daicoviciu surveyed the site (Daicoviciu 1950, 118). The traces of Roman constructions were identified When the railway towards the Baraolt mine was built (Székely 1962: 328-330).

As a result of documentary visits to Baraolt and the analysis of the current situation of the site (2014-2018), we decided to conduct a geomagnetic survey, in the area indicated by I. Paulovics as "tábor" ("camp"). The current land configuration is determined in its western side by the road to Racoșul de Sus and the south by the railway. We have investigated three sectors so 


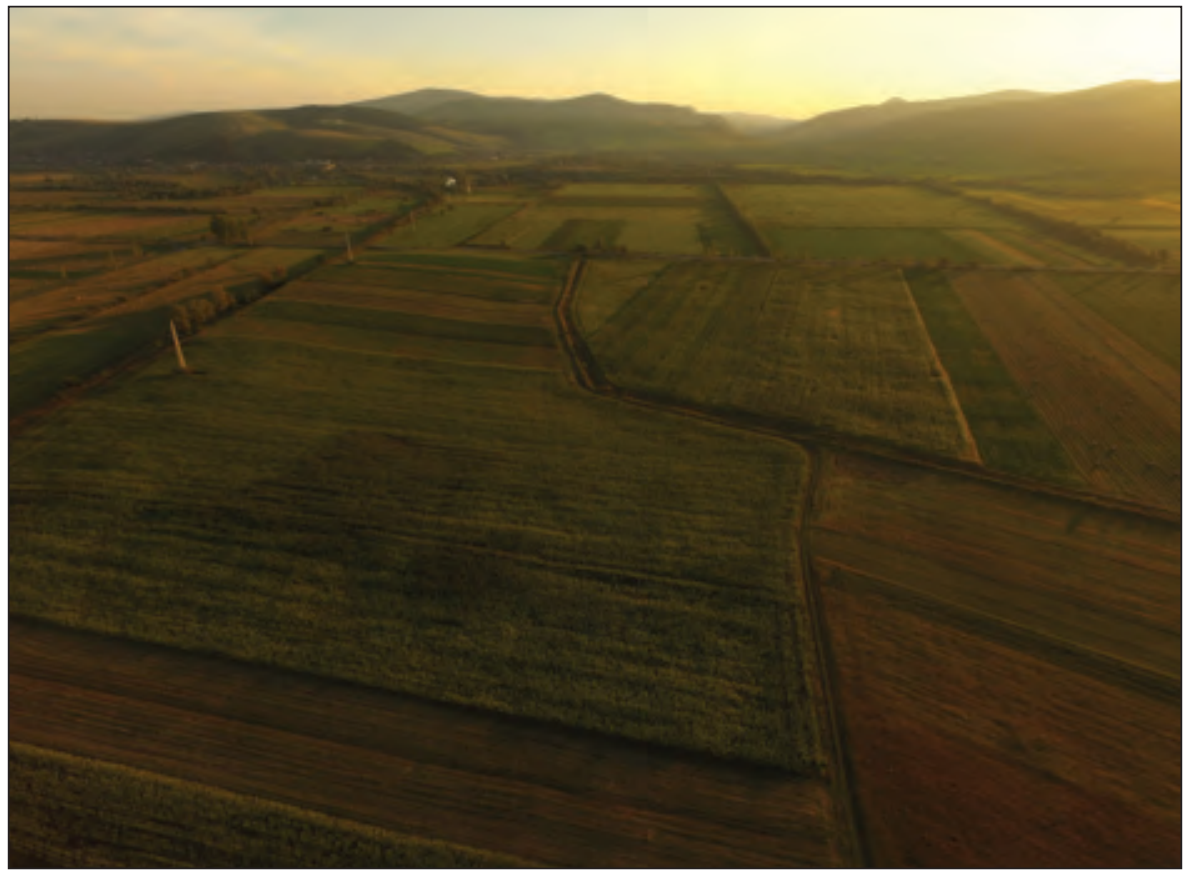

Figure 18. Baraolt. Aerial view on the area where the presumed fort lies

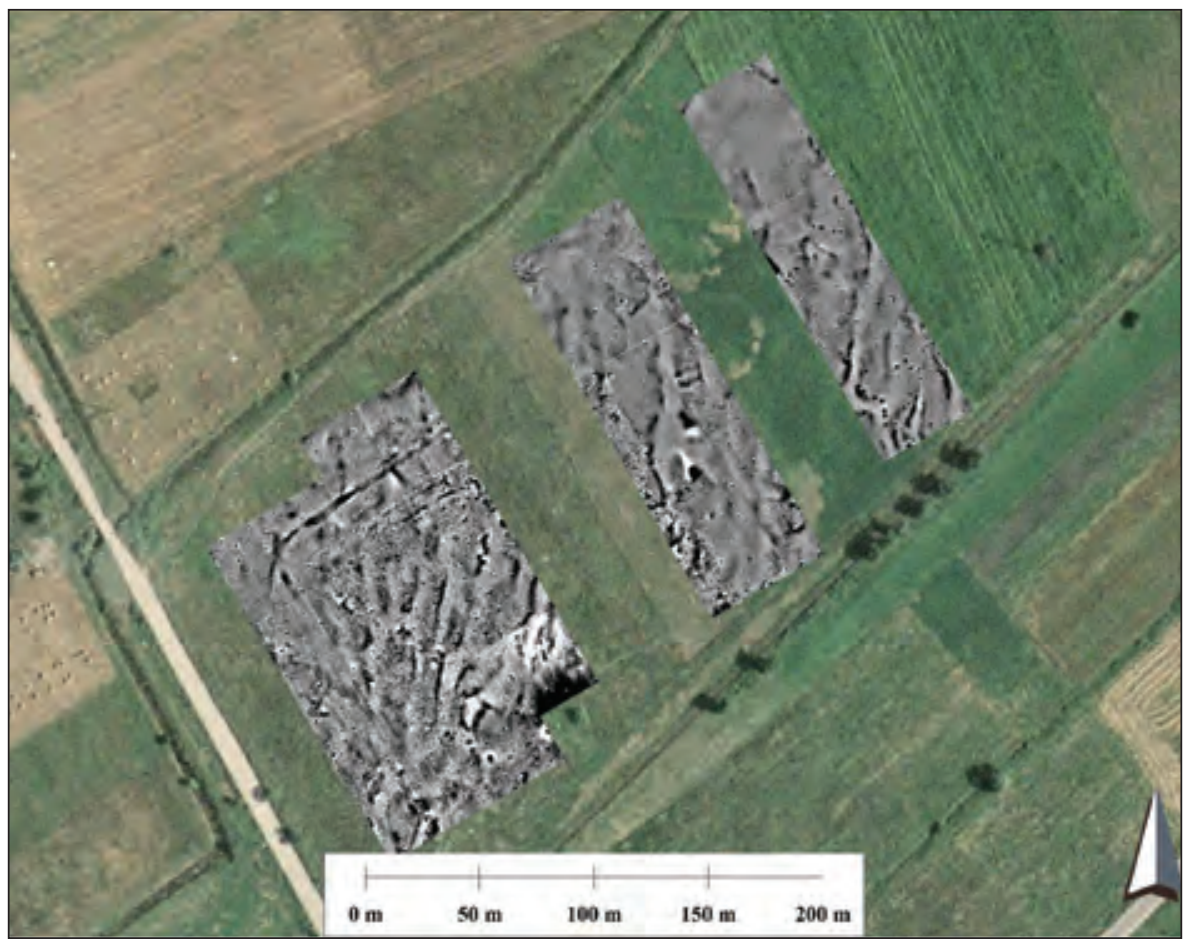

Figure 19. Baraolt. The results of magnetometric researches in the fortification 
far in order to reach the research objectives. Their dimensions and shapes were adapted to the ones of the land and to the need for avoiding a high voltage pillar or the currently inaccessible agricultural parcels (Figure 19). The assessment of the results we have had so far indicates that the site at Baraolt-Véczer farka presents the traces of a fortified settlement with a precinct wall and some inner complexes. One of these complexes placed in parallel to the presumed precinct wall, could represent the traces of a Roman barrack. Other anomalies we discovered point towards the existence of inhabitancy, probably of Roman origin, but they do not explain fully the site's functionality (Popa 2015a).

Besides the arguments provided by the archaeological and geophysical researches, some logical ones turn the hypothetical existence of a Roman camp at Baraolt-Véczer farka quite plausible. First, the distance between the „neighbouring” camps at Sânpaul and Olteni is of about $50-60 \mathrm{~km}$. Thus, it is highly probable that there was another Roman military fortification between these two points (Paulovics 1944: 60-62). Another logical indication to argue the existence of a Roman camp at Baraolt is the strategic position in controlling the communication ways: found at the intersection of two roads, one on an east-west direction (today the road from Augustin to Baraolt) and one on a north-south direction (today the road from Căpeni to Racoșul de Sus), the presumed camp would have controlled the entrance into the Racoș Gorge, through which the Olt river crosses the Perșani mountains. This assumption is backed up by the fact that also the other end of the Olt Gorge crossing (the western one) had been controlled and protected by the camp at Hoghiz (Țentea and Popa 2018), and between these two we can also find Dacian fortifications, such as the one at Tipia Ormenișului (Costea 2006). Based on the information we have had so far, we can assert that the traces found at Baraolt are of Roman origin, belonging to a military fortification, hoping that future researches will shed more light on this subject.

\section{Sânpaul}

Sânpaul is a locality in Harghita District, found on the Homorodul Mare river valley, in the Homoroade depression. Several Roman sites are known nearby Sânpaul (Cavruc 2000: 137). There is a Roman Fort, an open (civilian) settlement, as well as a site found nearby a presumed salt mine south of Sânpaul. The fort was found in the north side of the village, between the Unitarian Church and the brook called by locals "the Castle brook" (Figure 20). Older literature mentions that the ruins served as a rock source for building many of the properties nearby. Orbán was the first to presume the existence of a Roman 
camp at Sânpaul (Orbán 1868: 165), an opinion which was confirmed by the visit of Paulovics during the Second World War (Paulovics 1944: 53-59). Rescue archaeological diggings conducted between 1957 and 1958 revealed an entire series of Roman evidence, including traces of the inner wall (Ferenczi and Ferenczi 1960). The site caught the attention of specialists mostly due to the inscriptions revealed there (Russu 1988: 193-199). The most important inscription mentions a conductor of the salt mine (Mihailescu-Bîrliba 2016). Some historical and archaeological issues related to the Roman site from Sânpaul were tackled in other publications as well, either specialized (Timoc 2000) or general ones (Benea 2007; Cavruc and Chiricescu 2006: 54; Gudea 1997: 61, no. 37; Wollmann 1996: 244).

The archaeological site where it is presumed that salt was extracted in the Roman Period became known in specialised literature under the name of "Sânpaul-Minele romane" [Roman mines] (Cavruc 2000: 137). The site is found at about $1.5 \mathrm{~km}$ south-southeast of the village, on the right side of the road to Ocland, in the place called by natives "The brine well", or "the place where Romans exploited salt” (Russu 1988: 195) (Figure 21). In time, different items were collected in this area, such as coins, pottery fragments and the votive altar mentioned above. This item was discovered in the autumn of 1927 and is kept today at the National Szekler Museum in Sfântu Gheorghe. It is a votive altar made of limestone, with the dimensions of $94 \times 49 \times 43 \mathrm{~cm}$ (Russu 1988: 195-196, no. 248).

Today, we can still find two brine wells in this area (Chiricescu 2013: 218-219) and a salt-water spring - it is not properly arranged, but it is marked by saline efflorescence and halophile plants, as well as by many fragments of volcanic turfs. Besides these, at the surface, one could observe a series of wooden pillars placed deep in the ground. The pillars were about $50 \mathrm{~cm}$ high above the surface. Some of them had a diameter of about $40 \mathrm{~cm}$. The pillars seem to be arranged on two sides of a small ravine, the fact that allowed the birth of a hypothesis assuming that these could have pointed out the place where the entrance into the mine once was found (Chiricescu 2013: 220).

To verify the hypothesis of the existence of a salt mine nearby the brine spring, we decided to try a series of geomagnetic surveys of the area above the presumed entrance into the salt mine, that is in the area where one could suspect the presence of traces of some edifices belonging to the mine's infrastructure. The evaluation of our first results of magnetometric measurements conducted at "The salt mine from Sânpaul" allows us to affirm that the site is very rich in magnetic anomalies, which could be, at least 
$218 \mid$ PLURAL

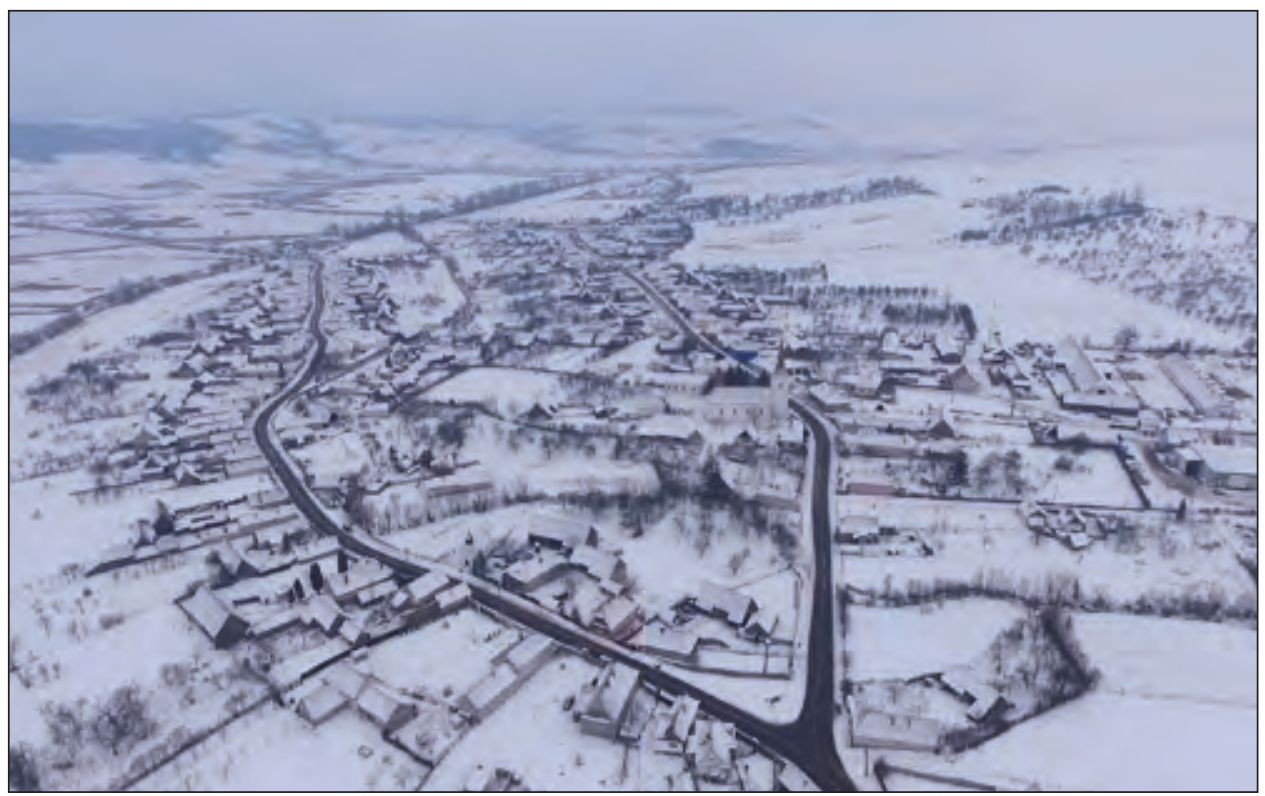

Figure 20. Sânpaul. Aerial view (from the north) upon the village

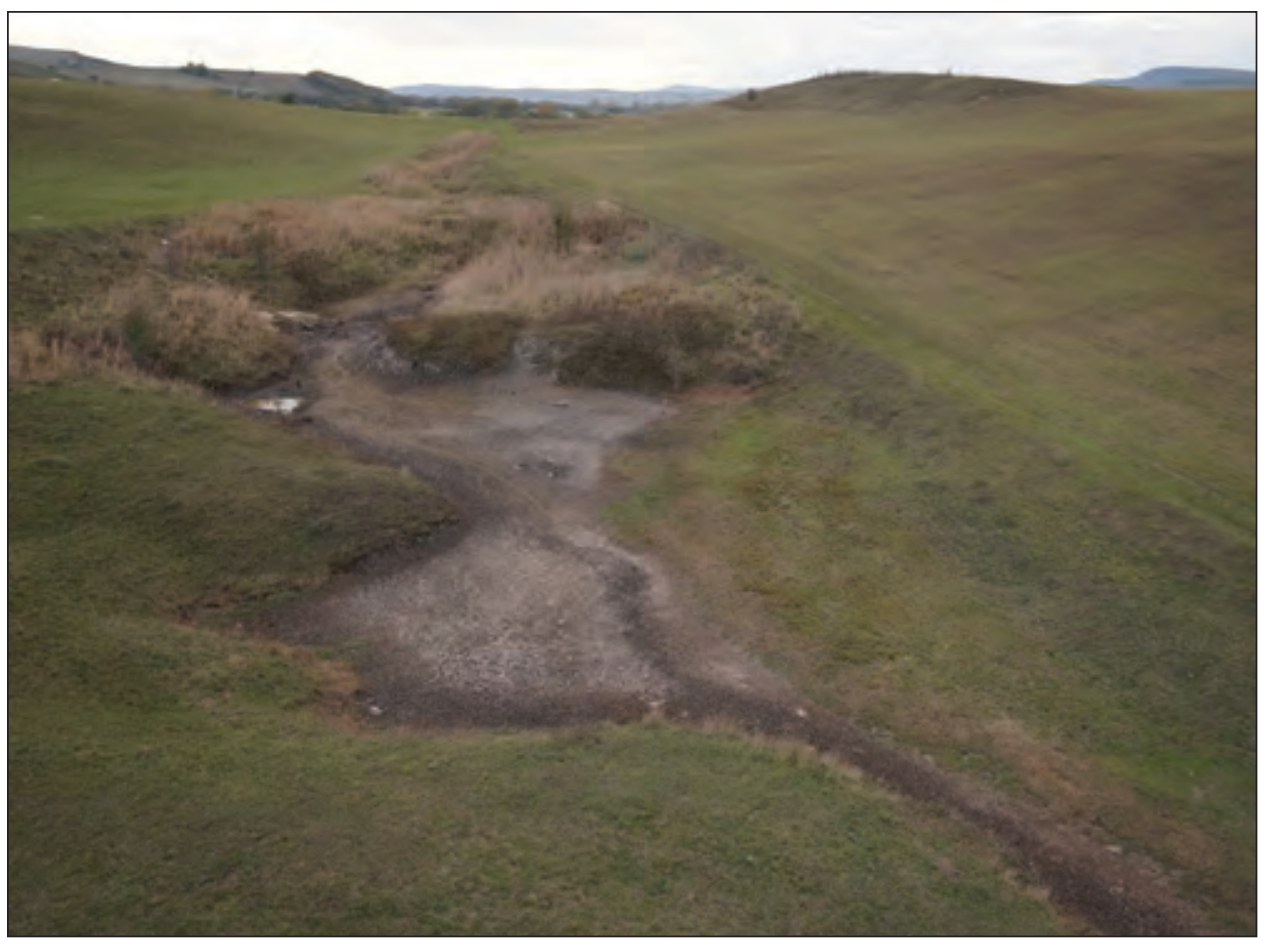

Figure 21. Sânpaul. Aerial view upon the salt-site 
partially, the result of anthropogenic activities (Figure 22). Extending the researches to a wider area around the surface marked by saline efflorescence and halophile plants could offer more information upon possible underground structures.

\section{A few general observations on the organisational system of the Roman borders in Dacia}

As mentioned above the configuration of the Frontiers of the Roman Empire (FRE) represents, first of all, a notion that is extremely dynamic in time. Besides the temporal factor, an outstanding role in the notion's dynamism is played by a series of geographic factors, which produce significant differences between the segments of the FRE found in different regions. The thematic study written to sustain the nomination strategy of the FRE in the UNESCO

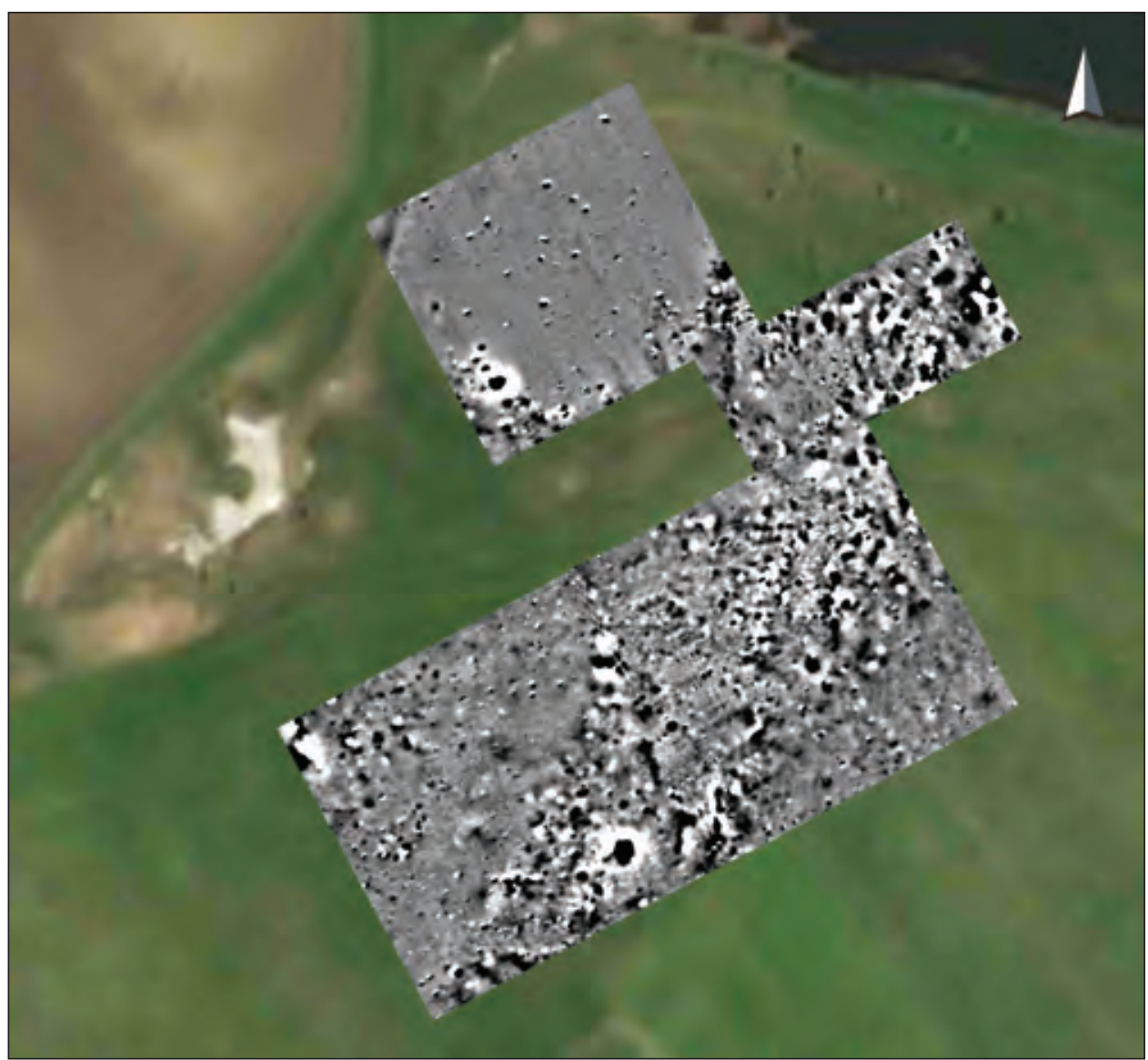

Figure 22. Sânpaul. The results of magnetometric researches in the area of the salt mine 
World Heritage List (Ployer, Polak and Schmidt 2017) defines the border in Roman province Dacia as a segment that is typologically different and distinct compared to all the other segments of the FRE in Europe (see also Chiricescu 2018). From this point of view, the way archaeologists and historians reconstruct, explain and interpret the FRE in Dacia is essential for the scientific documentation of the nomination dossier.

The subject is not new, as it has been discussed as a priority from the beginning of the archaeology of the Roman Limes in Dacia. One of the first attempts to define the essence of the border system in Roman Dacia belongs to Alfred von Domaszewski. His hypothesis was based on the assumption that each of the passes that crossed the Carpathians were controlled by Roman military fortifications, disposed concentrically around the legion camp at Apulum. To denominate this presumed defence system, von Domaszewski used the term of "Talsperre", which became part of the scientific literature, defined as the model to explain the structure of the borders in Roman Dacia (Domaszewski 1893: 242). Later, the term is resumed-at a more sceptical level-by Ernst Fabricius, who questions von Domaszewski's model when he talks about the situation in eastern and northern Dacia (Fabricius 1926, 642) ${ }^{1}$. Over time the "Talsperre" model has been accepted almost unanimously ${ }^{2}$ by Romanian historiography ${ }^{3}$.

Starting from von Domaszewski's idea, Nicolae Gudea developed, in a series of his papers, the model of the circular-concentric structure of the defence system in Roman Dacia that resembled a fan (Gudea 1974a; 1974b; 1977a; 1977b; 1997). The author admits that the Romans have dislocated around the legion camps at Potaissa and Apulum (those were seen as centres of the province's defence system) a row of so-called intermediary camps, disposed along the roads that connected the legion camps and the passes over the Carpathian Mountains. The auxiliary camps are considered to be the last row

1 Fabricius uses the term "Talsperre" once again, in the same publication, when he tries to explain the role of the wall that blocked the Skiffa River (Fabricius 1926: 663). See also (Cagnat 1913: 534).

2 A disapproving attitude towards generalising the "Talsperre" model was been expressed at the time by Mihail Macrea (1969: 218-219).

3 For example, when he took the floor at the celebration of 100 years of the German Archaeology Institute, Emil Panaitescu spoke about the "Roman fortifications ... disposed on river valleys", thus hinting to the "Talsperre" Model (Panaitescu 1930: 301-302). In the same measure, Constantin Daicoviciu, who had, at that time, a trendsetter role in Romanian archaeology, used the "Talsperre" model to explain the structure of the fortification system in Dacia (Daicoviciu 1938: 44). Also, in the History of Romanians the authors make reference to the term introduced by von Domaszewski in the scientific circuit (Protase and Suceveanu 2010: 116). 
of such fortifications, disposed of right in front of these passes or gorges. These should represent the external defence line of Roman Dacia ${ }^{4}$. Gudea developed von Domaszewski's idea about the "Talsperre" by marking 11 distinct segments of the Roman border in Dacia on the line of the external camps (Gudea 1974a: 48-49; 1997: 4 fig. 1). The textual description of these border segments points out clearly that we deal with a series of research conventions, which cannot be identified in the field (Gudea 1974b).

The logic behind this system, regardless of what we call it-circular or fanlike-is hard to be applied to the entire Dacia Province. The biggest perplexity is raised by the line of the so-called intermediary camps (e.g., Hoghiz, Cincșor and Feldioara) (Gudea 1997: nos. 43, 44, 45). These military fortifications, disposed somewhat in the middle of the Province and designed for the longterm stationing of the auxiliary troops, were supposed to oversee the roads from the legion camps towards the camps on the border. None of Gudea's works admits any chronological or typo-functional differences between the "intermediary" and "auxiliary" camps. The chronology of the Roman camps in Dacia, including the "intermediary" ones, is determined by the generalized thesis related to the erection of the province's border as soon as it had been conquered by Trajan. Thus, all the camps in Dacia were supposed to have been built during Emperor Trajan's reign (Gudea and Lobüscher 2006: 32-33). We need to mention the fact that the chronological differences in erecting the different Roman fortifications in Dacia, postulated by Buday Arpad at his time has never been discussed in the archaeological literature, except a rather polemical argumentation found in one of the earliest articles written by Constantin Daicoviciu (Daicoviciu 1936).

The field analysis conducted in south-eastern Transylvania indicates that the location of the border camps (Figure 1) can be most often connected to the model proposed by von Domaszewski: the fortification at Brețcu is placed in front of the Oituz Pass, Boroșneu Mare is located at the entrance into the Brașov Depression when approaching from Buzău Pass, the fortification at Olteni assures the control over the Olt River (the access in the region from the north). The camp at Râșnov is located on the road to enter the Brașov Depression through Rucăr-Bran Pass. A prominent exception is a fortification at Comolău-Reci, which is found on the bank of the Negru River and not in front or next to a pass over the mountains. A remarkable position is held by the presumed fortification at Baraolt. By its geographic layout, it was supposed to oversee the access into the region through the Olt Defile. One particular

4 In some works the defence system of Roman Dacia is mentioned to be a "circular" one (Gudea and Lobüscher 2006: 32). 
aspect being that on the other side of the Defile one can find Roman fortified sites, such as the one at Hoghiz (T,entea and Popa 2018) or Ungra/Rupea (Gridan, Udrea and Hegyi 2017).

The identification of the border-line of Dacia Province in the area close to Baraolt lies within the same category of curiosities: most of the publications show this border on a north-west towards the south-east direction, from Sânpaul to Olteni, under the shape of a straight line ${ }^{5}$, although any topographic map indicates that this line intersects the Perșani and the Baraolt Mountains. In this context, we do not exclude the fact that the road that connected the two fortifications might have crossed the Homoroade Valley, from Sânpaul to Hoghiz, then through the Olt Defile to Baraolt, and then towards Olteni.

\section{Acknowledgement}

This research is part of the Project „Preservation by the development of sustainable strategies for better protection of the UNESCO World Heritage Sites from Romania” - archaeoheritage.ro/hero, supported by the National Research Council (CNCS) - Executive Agency for Higher Education, Research, Development and Innovation Funding (UEFISCDI), PN-III-P4-ID-PCE-2016-0737 and implemented under the auspices of the Institute of Archaeology of the Romanian Academy, Iasi Branch, Romania.

\section{References}

Benea, Doina. 2007. "Cu privire la administrarea salinelor din Dacia romană.” Analele Banatului 15: 41-46.

Bordi, Zsigmond Lóránd, and Al. Popa. 2013. "Castrul roman de la Boroșneu Mare: o sută de ani de la prima cercetare arheologică sistematică.” Acta Siculica (Sf. Gheorghe): 261-308.

Cagnat, René. 1913. L'armée romaine d'Afrique et l'occupation militaire de l'Afrique sous les empereurs. [2. éd.] ed. Paris: Leroux.

Cavruc, Valeriu. 2000. Repertoriul arheologic al județului Harghita, Monografii arheologice. Sf. Gheorghe.

Cavruc, Valeriu, Botond Bartok, and Mihai Bărbulescu. 1998. Repertoriul arheologic al județului Covasna. Vol. 1, Monografii Arheologice. Sfântu Gheorghe.

Cavruc, Valeriu, and Andrea Chiricescu, eds. 2006. Sarea, Timpul și Omul. Sfîntu Gheorghe: Editura Angustia.

Chiricescu, Andrea. 2013. Civilizația tradițională a sării în estul Transilvaniei: raport de cercetare. Sfântu Gheorghe: Angustia.

5 See the representative approach in The History of the Romanians (Protase and Suceveanu 2010). 
Chiricescu, Andrea. 2018. «Frontiera Imperiului Roman și UNESCO. Observații pe marginea unui studiu recent apărut.» Plural. Journal of the History and Geography Department,"Ion Creangă" State Pedagogical University 6 (2): 216-230.

Costea, Florea. 2006. Augustin - Tipia Ormenișului. Brașov: C2 Design.

Daicoviciu, C. 1936. "Dacica. În jurul unor probleme din Dacia romană.” Anuarul Institutului de Studii Clasice II (1933-1935): 240-256.

Daicoviciu, C. 1938. La Transylvanie dans l'antiquité. Bukarest.

Daicoviciu, C. 1950. «Granița de Est a Daciei și triburile libere dela hotarele de răsărit ale Daciei. Rezultatul cercetărilor de pe șase șantiere din jud. Trei Scaune.» Studii și Cercetări de Istorie Veche 1: 115-122.

Domaszewski, A. von. 1893. „Zur Geschichte der römischen Provinzialverwaltung.“ Rheinisches Museum für Philologie. N. F 48: 240-247.

Fabricius, Ernst. 1926. „Limes.“ In Paulys Real-Encyclopädie der Classischen Altertumswissenschaft, edited by Georg Wissowa, 572-671. Stuttgart.

Ferenczi, G., and I. Ferenczi. 1960. „Săpăturile de salvare din 1957-1958 de la Sînpaul.“ Materiale și Cercetări Arheologice VII: 401-405.

Gridan, Silviu, Petru Udrea, and Alexandru Hegyi. 2017. "Castrul de la Ungra, jud. Brașov. Cercetări multidisciplinare.” In In honorem Doina Benea. Interdisciplinaritate în Arheologie și Istorie, edited by Sorin Forțiu, 851-883. Szeged: JATEPress Kiadó.

Gudea, Nicolae. 1974a. "Das Verteidigungssystem des römischen Dacien. Der heutige Stand der Forschung." Saalburg Jahrbuch. Bericht des Saalburg Museums 31: 41-49.

Gudea, Nicolae. 1974b. „Sistemul defensiv al Daciei romane. I. Stadiul actual al cerctărilor.” Apulum 12: 182-192.

Gudea, Nicolae. 1977a. „Der Limes Dakiens und die Verteidigung der obermoesischen Donaulinie von Trajan bis Aurelian." In Principat, edited by Hildegard Temporini, 849-887.

Gudea, Nicolae. 1977b. «Limesul Daciei romane de la Traianus (106) la Aurelianus (275).» Acta Musei Porolissensis 1: 97-113.

Gudea, Nicolae. 1997. «Der dakische Limes. Materialien zu seiner Geschichte.» Jahrbuch des Römisch Germanischen Zentralmuseums Mainz 44 (2): 497-609.

Gudea, Nicolae, and Thomas Lobüscher. 2006. Dacia. Eine römische Provinz zwischen Karpaten und Schwarzem Meer, Zaberns Bildbände zur Archäologie. Sonderbände der Antiken Welt. Mainz.

Macrea, M. 1969. Viața în Dacia Romană. București: Editura Ştiințifică.

Macrea, M., L. Buzdugan, G. Ferenczi, K. Horedt, I. Popescu, and I. I. Russu. 1951. „Despre rezultatele cercetărilor întreprinse de șantierul arheologic Sf. Gheorghe Brețcu." Studii și cercetări de istorie veche și arheologie 2 (1): 285-311.

Mihăilescu-Bîrliba, Lucrețiu. 2016. „Les salines en Dacie romaine : remarques sur le personnel administratif." Studia Antiqua et Archaeologica 22 (1): 51-58.

Orbán, Balász. 1868. A Székelyföld leírása történelmi, régészeti, természetrajzi s népismei szempontból. I. Udvarhelyszék. Pest. 
Panaitescu, Emil. 1929. Le limes dacique. Nouvelles fouilles et nouveaux résultats. Vol. 15, Bulletin de la Section Historique de l'Académie Roumaine. Bucharest.

Panaitescu, Emil. 1930. «Neuere Ausgrabungen in Dacia Superior (Siebenbürgen).» In Bericht über die Hundertjahrfeier, 21-25 April 1929, Deutsches Archäologisches Institut, 300-302. Berlin: Walter der Gruyter.

Paulovics, Istvan. 1944. Dácia keleti határvonala és az úgynevezett "dák” ezüst kincsek kérdése. Kolozsvár.

Ployer, René, Marinus Polak, and Ricarda Schmidt. 2017. The Frontiers of the Roman Empire. A Thematic Study and Proposed World Heritage Nomination Strategy Advised by Icomos-International and commissioned be the Intergovernmental Committee of the 'Frontiers of the Roman Empire' World Heritage Site (UK, DE) and the Bratislava Group. Vienna / Nijmegen / Munich.

Popa, Al. 2013. «Măsurări de susceptibilitate magnetică și cartarea fosforului în castrul roman de la Brețcu, jud. Covasna [Measurements of Magnetic Susceptibility and Phosphate Mapping at the roman Camp from Brețcu, Covasna County].» In In Memoriam Liviu Măruia. Simpozion Arheovest, Interdisciplinaritate în Arheologie și Istorie, 525-544. Timișoara.

Popa, Al. 2014. "Câteva consemnări asupra castrului roman de la Brețcu în lumina noilor cercetări.” Angustia 17: 235-244.

Popa, Al. 2015a. «Castrul roman de la Baraolt? Contribuții la repertoriul arheologic al județului Covasna.» Angustia 19: 163-174.

Popa, Al. 2015b. „Interdisziplinäre Forschungen im Auxiliarkastell von Brețcu im südöstlichen Siebenbürgen." In XXII International Limes Congress 2012 - Bulgaria - Roman Empire Frontiers, edited by Ludmil Vagalinski and Nikolay Sharankov, 829-838. Rousse/Bulgaria.

Popa, Al., and Zsigmond Lóránd Bordi. 2016. Studii asupra graniţelor romane din Dacia. Fortificația de la Comolău. Vol. 1, Studii și Cercetäri asupra frontierelor Imperiului Roman de pe teritoriul României. Cluj-Napoca.

Popa, Al., S. Cociș, Christina Klein, Corneliu Gaiu, and Nicoleta Man. 2010a. "Geophysikalische Prospektionen in Ostsiebenbürgen. Ein deutsch-rümänischmoldauisches Forschungsprojekt an der Ostgrenze der römischen Provinz Dacia.” Ephemeris Napocensis (Cluj) 20: 101-128.

Popa, Al., Vlad-Andrei Lăzărescu, Alpár Dobos, and Radu Zăgreanu. 2010b. „Vorläufige Ergebnisse der Phosphatkartierung im römischen Kastell von Brețcu.“ Revista Bistriței 23: 69-74.

Popa, Alexandru. 2018. «Frontiera Imperiului Roman din Dacia în drum spre Lista Patrimoniului Mondial UNESCO. Probleme și responsabilități pentru cercetarea arheologică, protecția patrimoniului și turism.» Plural. Journal of the History and Geography Department,"Ion Creangă" State Pedagogical University 6 (2): $170-184$.

Protase, Dumitru, and Alexandru Suceveanu, eds. 2010. Istoria Românilor II. Dacoromani, romanici, alogeni. Ediția 2 ed. București. 
ROGOV (2016) = Romanian Government, Ministry of Culture. Decree no. 2254/13.04.2016.

Russu, I. I. 1988. Dacia Superior (zona răsăriteană). Vol. III/4, Inscripțiile Daciei Romane. București.

Székely, Zoltán. 1962. "Sondajele efectuate de Muzeul regional din Sf. Gheorghe." Materiale și Cercetări de Arheologie 8: 325-340.

Székely, Zoltán. 1975. «Noi descoperiri din epoca romană din sudestul Transilvaniei.» In Zoltán Székely. Lucrări alese, edited by Zsolt Székely, 138-141. Sf. Gheorghe.

Székely, Zoltán. 1993. "Castrul roman de la Olteni. Noi rezultate ale cercetărilor de teren din anii 1987-1988.» Arheologia Moldovei 16: 279-282.

Țentea, Ovidiu. 2013. Modele ale civilizației romane in provinciile dunărene între identități locale şi valori universale, Colecția Aula Magna. Bucureşti: Ed. Muzeului Naţional al Literaturii Române.

Țentea, Ovidiu, and Alexandru Popa. 2018. «Castrul și băile romane de la Hoghiz - rezultatele recente ale prospecțiunilor geofizice.» Cercetări arheologice 24: $135-141$.

Timoc, Călin. 2000. «Despre castrul și vicus-ul militar de la Sânpaul (jud. Harghita).» Apulum 37 (1): 397-399.

UNESCO (2019) = UNESCO World Heritage Centre. "3rd Meeting Bratislava Group”. Online: whc.unesco.org/uploads/nominations/430ter.pdf.

Wollmann, Volker. 1996. Mineritul metalifer, extragerea sării și carierele de piatră in Dacia romană. Der Erzbergbau, die Salzgewinnung und die Steinbrüche im römischen Dakien. Vol. 13, Bibliotheca Musei Napocensis. București: Ed. Museion.

\section{Frontierele Imperiului Roman în Dacia de Est. Rezultatele preliminare ale cercetării efectuate în contextul Programului Național de Limes din România}

\section{Rezumat}

Urmele vizibile și invizibile ale Frontierei Romane din Dacia au fost, de mult timp, unul dintre cele mai reprezentative situri arheologice din România și, în special, din Transilvania. Pe de o parte, frontiera romană din Transilvania, cunoscută şi sub numele de Limes, simbolizează o graniță între lumea greco-romană și civilizațiile locale descopetite în regiunile de la nord de Dunăre. Pe de altă parte, mai degrabă avem de-a face cu o zonă de contact între cele două părți ale oicumenei antice. România a decis să se alăture inițiativei internaționale cunoscute sub denumirea de Frontierele Imperiului Roman (FRE), site-ul UNESCO, prin înscrierea în Lista patrimoniului mondial componentele de pe teritoriul său - limesul dacic și segmentele frontierei romane de pe Dunăre. Activitatea de pregătire a nominalizărilor este condusă de mai multe instituții. Alături de 
Institutul Național al Patrimoniului, care este responsabil, prin tradiție, de toate nominalizările UNESCO din România, activitatea implică și Muzeul Național de Istorie din București, Muzeul Național de Istorie a Transilvaniei din Cluj-Napoca și Muzeul Național al Carpaților Orientali din Sf. Gheorghe. Comisia Națională pentru Limes a fost înființată pentru a coordona toate activitățile întreprinse și pentru a asigura o comunicare adecvată între instituțiile menționate, atât în cadrul parteneriatului național, cât și cu partenerii internaționali.

Cuvinte cheie: Dacia romană, frontiera romană, Limes, Programul Național al Limesului.

Alexandru Popa, National Museum of the Eastern Carpathians (Sfântu Gheorghe, Romania), e-mail: alex.popa@mncr.ro 